\title{
Hidden evolutionary complexity of Nucleo-Cytoplasmic Large DNA viruses of eukaryotes
}

Natalya Yutin and Eugene V Koonin ${ }^{*}$

\begin{abstract}
Background: The Nucleo-Cytoplasmic Large DNA Viruses (NCLDV) constitute an apparently monophyletic group that consists of at least 6 families of viruses infecting a broad variety of eukaryotic hosts. A comprehensive genome comparison and maximum-likelihood reconstruction of the NCLDV evolution revealed a set of approximately 50 conserved, core genes that could be mapped to the genome of the common ancestor of this class of eukaryotic viruses.
\end{abstract}

Results: We performed a detailed phylogenetic analysis of these core NCLDV genes and applied the constrained tree approach to show that the majority of the core genes are unlikely to be monophyletic. Several of the core genes have been independently acquired from different sources by different NCLDV lineages whereas for the majority of these genes displacement by homologs from cellular organisms in one or more groups of the NCLDV was demonstrated.

Conclusions: A detailed study of the evolution of the genomic core of the NCLDV reveals substantial complexity and diversity of evolutionary scenarios that was largely unsuspected previously. The phylogenetic coherence between the core genes is sufficient to validate the hypothesis on the evolution of all NCLDV from a common ancestral virus although the set of ancestral genes might be smaller than previously inferred from patterns of gene presence-absence.

\section{Background}

Viruses are ubiquitous, obligate, intracellular parasites of all cellular life forms that rely on the host cell translation system, metabolism and, in many cases, the replication and transcription systems, for their reproduction. There is no evidence that all viruses have a monophyletic origin, at least not under the traditional concept of monophyly. Indeed, not a single gene is conserved in the genomes of all known viruses although a small group of "viral hallmark genes" encoding some of the key proteins involved in genome replication and virion structure formation are shared by large, diverse subsets of viruses $[1,2]$. However, several large groups of viruses infecting diverse hosts do appear to share common ancestry in the strict sense, that is, to have evolved from the same ancestral virus, as indicated by the conservation of sets

\footnotetext{
* Correspondence: koonin@ncbi.nlm.nih.gov

National Center for Biotechnology Information, National Library of Medicine, National Institutes of Health, Bethesda, MD 20894, USA
}

of genes encoding proteins responsible for many functions essential for virus reproduction.

One of the largest viral divisions that seem to be monophyletic includes 6 recognized families and a $7^{\text {th }}$ candidate family of viruses with large DNA genomes that infect diverse eukaryotes and are collectively known as Nucleo-Cytoplasmic Large DNA Viruses (NCLDV) [3-6]. The formally recognized NCLDV families are Poxviridae, Asfarviridae, Iridoviridae, Ascoviridae, Phycodnaviridae, and Mimiviridae; in addition, the recently discovered Marseillevirus and the related Lausannevirus could not be assigned to any of the 6 families, and are likely to become founding members of a new family $[7,8]$. Hereinafter we speak of 7 NCLDV families for the sake of simplicity.

By far the most thoroughly studied group of the NCLDV are the Poxviridae, the family of animal viruses that include a major human pathogen, the smallpox virus, important animal pathogens, such as rabbit
C Biomed Central

(c) 2012 Yutin and Koonin; licensee BioMed Central Ltd. This is an Open Access article distributed under the terms of the Creative Commons Attribution License (http://creativecommons.org/licenses/by/2.0), which permits unrestricted use, distribution, and reproduction in any medium, provided the original work is properly cited. 
myxoma virus, as well as vaccinia virus (VACV), one of the best characterized models of molecular biology [9]. Another family of the NCLDV that has recently become a major focus of attention is the Mimiviridae that includes giant viruses infecting amoeba and probably algae [10-13]. The genome of the prototype virus of this family, Acanthamoeba polyphaga Mimivirus [14], slightly exceeds one megabase $(\mathrm{Mb})$, and other related viruses possess even larger genomes [15,16], so the Mimiviridae are undisputed genome size record holders in the virosphere. Indeed, in terms of genome size and complexity, the NCLDV eclipse numerous parasitic bacteria, and approach the simplest free-living prokaryotes.

The NCLDV infect animals and diverse unicellular eukaryotes, and either replicate exclusively in the cytoplasm of the host cells, or encompass both cytoplasmic and nuclear stages in their life cycle. Most of the NCLDV do not strongly depend on the host replication or transcription systems for completing their replication $[9,17]$. The autonomous life style of the NCLDV is supported by a set of conserved proteins that are encoded in the viral genomes and mediate most of the processes essential for viral reproduction. These essential, conserved proteins include DNA polymerases, helicases, and primases responsible for DNA replication, RNA polymerase subunits and transcription factors that function in transcription initiation and elongation, Holliday junction resolvases and topoisomerases involved in genome DNA processing and maturation, ATPase pumps mediating DNA packaging, molecular chaperones involved in capsid assembly and capsid proteins themselves [3-5]. Although several viral hallmark genes are shared by NCLDV and other large DNA viruses, such as herpesviruses, baculoviruses and some bacteriophages [2], the conservation of the large set of core genes clearly demarcates the NCLDV as a distinct, most likely monophyletic class of viruses $[4,6]$. More specifically, reconstructions of the ancestral NCLDV genome composition using maximum parsimony and maximum likelihood methods have delineated a set of approximately 50 genes that are inferred to have been responsible for the key functions in the reproduction of the last common ancestor of the NCLDV [5].

The core, presumably ancestral set of the NCLDV genes was delineated using sequence similarity-based methods that have been previously employed for identification of clusters of orthologous genes in diverse cellular life forms. The comparative genomic analysis underlying these reconstructions was deliberately limited to the NCLDV genomes to simplify the analysis and to facilitate detection of distant relationships between viral proteins. Indeed, some of the core NCLDV proteins, such as for example the packaging ATPases and the disulfide chaperones, show only weak sequence similarity between the viral families. Moreover, for some of the NCLDV genes with important functions in virus reproduction, indications of complex evolutionary histories have been obtained. The showcase for such evolutionary complexity is the viral DNA ligase which is represented by two distantly related forms across the NCLDV families. A maximum likelihood reconstruction based on the presence-absence of conserved genes in the viral genomes has implied that one of the two forms, the ATP-dependent DNA ligase, was the ancestral form that was present in the genome of the prototype NCLDV but was replaced by the distantly related NAD-dependent ligase in several viral lineages. However, when the reconstruction was supplemented by phylogenetic analysis of the two forms of DNA ligase, the opposite conclusion has been reached, namely that the NAD -dependent ligase was the ancestral form in NCLDV that was displaced by the ATP-dependent ligase on several independent occasions [18]. This change in perspective occurred because phylogenetic analysis indicated that the ATP-dependent ligases from different lineages of the NCLDV clustered with distinct groups of eukaryotic homologs whereas the NAD-dependent ligases of the NCLDV appeared to be monophyletic. In the same vein, complex phylogenies suggestive of multiple horizontal gene transfer have been observed for several core NCLDV genes such as thymidine kinase or the two subunits of ribonucleotide reductase [19].

Taken together, these findings imply that some of the apparently conserved genes of the NCLDV might actually have complex histories which could include independent (convergent) acquisition of these genes from different cellular organisms as well as displacement of ancestral viral gene by homologs of cellular provenance. This line of reasoning prompted us to perform a comprehensive phylogenetic analysis of the set of the putative ancestral NCLDV genes. Here we present the results of this analysis which suggest that, although the existence of a common ancestor of the NCLDV is beyond reasonable doubt, most of the conserved NCLDV genes indeed had complex evolutionary histories.

\section{Results}

\section{Approach and rationale}

Maximum likelihood reconstruction of the gene repertoire of the putative ancestral NCLDV has revealed a core consisting of approximately 50 viral genes (Table 1 ). Most of these genes are present in various subsets of the NCLDV genomes rather than all genomes (Additional file 1) but high likelihoods of ancestral provenance have been estimated for each of them, with the absences accordingly attributed to lineage-specific gene loss. We constructed multiple alignments and position-specific scoring matrices for each of the ancestral NCLDV genes 
Table 1 Evolutionary scenarios for the ancestral NCLDV genes

\begin{tabular}{|c|c|c|c|c|c|}
\hline NCVOG $[3,4]$ & $\begin{array}{l}\text { Vaccinia } \\
\text { virus gene } \\
\text { number }^{\mathrm{a}}\end{array}$ & $\begin{array}{l}\text { Functional } \\
\text { category }\end{array}$ & $\begin{array}{l}\text { \# of viral } \\
\text { families/ } \\
\text { genomes }\end{array}$ & NCVOG annotation & $\begin{array}{l}\text { Evolutionary scenario from constrained } \\
\text { tree analysis }\end{array}$ \\
\hline NCVOG0038 & E9L & $\begin{array}{l}\text { DNA replication, } \\
\text { recombination } \\
\text { and repair }\end{array}$ & $6 / 45$ & $\begin{array}{l}\text { DNA polymerase elongation } \\
\text { subunit family B }\end{array}$ & $\begin{array}{l}\text { Monophyletic NCLDV, common origin with } \\
\text { baculoviruses and possibly herpesviruses }\end{array}$ \\
\hline NCVOG0023 & D5R & $\begin{array}{l}\text { DNA replication, } \\
\text { recombination } \\
\text { and repair }\end{array}$ & $6 / 45$ & D5-like helicase-primase & $\begin{array}{l}\text { Monophyletic NCLDV but displaced by a } \\
\text { bacteriophage homolog in phycodnaviruses. }\end{array}$ \\
\hline NCVOG1060 & G5R & $\begin{array}{l}\text { DNA replication, } \\
\text { recombination } \\
\text { and repair }\end{array}$ & $5 / 35$ & $\begin{array}{l}\text { FLAP-like endonuclease } \\
\text { XPG (cd00128) }\end{array}$ & $\begin{array}{l}\text { Possibly monophyletic NCLDV although } \\
\text { displacement by a phage homolog in } \\
\text { poxviruses cannot be ruled out; loss in } \\
\text { phycodnaviruses and subsequent acquisition of } \\
\text { a eukaryotic homolog by E. huxlei virus }\end{array}$ \\
\hline NCVOG0036 & H6R & $\begin{array}{l}\text { DNA replication, } \\
\text { recombination } \\
\text { and repair }\end{array}$ & $3 / 23$ & DNA topoisomerase IB & Possibly monophyletic NCLDV \\
\hline NCVOG0037 & None & $\begin{array}{l}\text { DNA replication, } \\
\text { recombination } \\
\text { and repair }\end{array}$ & $6 / 15$ & DNA topoisomerase II & $\begin{array}{l}\text { Polyphyletic NCLDV, gene acquired } \\
\text { from different eukaryotes }\end{array}$ \\
\hline NCVOG0035 & None & $\begin{array}{l}\text { DNA replication, } \\
\text { recombination } \\
\text { and repair }\end{array}$ & $3 / 7$ & $\begin{array}{l}\text { NAD + dependent DNA } \\
\text { ligase (smart00532) }\end{array}$ & Monophyletic NCLDV \\
\hline NCVOG0034 & A50R & $\begin{array}{l}\text { DNA replication, } \\
\text { recombination } \\
\text { and repair }\end{array}$ & $4 / 19$ & $\begin{array}{l}\text { ATP-dependent } \\
\text { DNA ligase } \\
\text { (pfam01068, PRK01109) }\end{array}$ & $\begin{array}{l}\text { Polyphyletic NCLDV, gene acquired from } \\
\text { different eukaryotes }\end{array}$ \\
\hline NCVOG0278 & $\mathrm{A} 22 \mathrm{R}$ & $\begin{array}{l}\text { DNA replication, } \\
\text { recombination } \\
\text { and repair }\end{array}$ & $5 / 36$ & $\begin{array}{l}\text { RuvC, Holliday junction } \\
\text { resolvases (HJRs); cl00243. } \\
\text { Extended Pox_A22, } \\
\text { Poxvirus A22 family } \\
\text { (pfam04848). Marseille } \\
\text { virus protein lacks C-term } \\
\text { conserved positions. }\end{array}$ & $\begin{array}{l}\text { Insufficient sequence } \\
\text { conservation for reliable phylogenetic analysis }\end{array}$ \\
\hline NCVOG0004_APa & None & $\begin{array}{l}\text { DNA replication, } \\
\text { recombination } \\
\text { and repair }\end{array}$ & $4 / 6$ & $\begin{array}{l}\text { AP (apurinic) } \\
\text { endonuclease family } 2\end{array}$ & Strongly supported monophyly of NCLDV \\
\hline NCVOG0004_NT ${ }^{\mathrm{a}}$ & None & $\begin{array}{l}\text { DNA replication, } \\
\text { recombination } \\
\text { and repair }\end{array}$ & $3 / 4$ & $\begin{array}{l}\text { Nucleotidyltransferase } \\
\text { (DNA polymerase } \\
\text { beta family) }\end{array}$ & $\begin{array}{l}\text { Polyphyletic NCLDV, gene acquired from } \\
\text { different eukaryotes }\end{array}$ \\
\hline NCVOG1192 & None & $\begin{array}{l}\text { DNA replication, } \\
\text { recombination } \\
\text { and repair }\end{array}$ & $4 / 13$ & $\begin{array}{l}\text { YqaJ viral recombinase } \\
\text { family (pfam09588) }\end{array}$ & Possibly monophyletic NCLDV \\
\hline NCVOG0024 & None & $\begin{array}{l}\text { DNA replication, } \\
\text { recombination } \\
\text { and repair }\end{array}$ & $3 / 4$ & $\begin{array}{l}\text { Superfamily II helicase } \\
\text { related to herpesvirus } \\
\text { replicative helicase } \\
\text { (origin-binding protein } \\
\text { UL9), pfam03121 }\end{array}$ & $\begin{array}{l}\text { Limited sequence similarity between proteins } \\
\text { from different NCLDV; probable polyphyletic } \\
\text { origin; possibly not an ancestral NCLDV gene }\end{array}$ \\
\hline NCVOG1115 & D4R & $\begin{array}{l}\text { DNA replication, } \\
\text { recombination } \\
\text { and repair }\end{array}$ & $3 / 23$ & Uracil-DNA glycosylase & $\begin{array}{l}\text { Present in only a few NCLDV; uncertain, } \\
\text { monophyly of the NCLDV cannot be ruled out }\end{array}$ \\
\hline NCVOG0274 & $J 6 R$ & $\begin{array}{l}\text { Transcription } \\
\text { and RNA } \\
\text { processing }\end{array}$ & $6 / 36$ & $\begin{array}{l}\text { DNA-directed RNA } \\
\text { polymerase subunit } \\
\text { alpha }\end{array}$ & $\begin{array}{l}\text { Displacement of ancestral NCLDV gene in } \\
\text { mimivirus and ASFV with eukaryotic RNAP2 and } \\
\text { RNAP1 subunit genes, respectively; loss in most } \\
\text { phycodnaviruses. Ancestral NCLDV gene possibly } \\
\text { derived from eukaryote RNAP I }\end{array}$ \\
\hline NCVOG0271 & $A 24 R$ & $\begin{array}{l}\text { Transcription and } \\
\text { RNA processing }\end{array}$ & $6 / 36$ & $\begin{array}{l}\text { DNA-directed RNA } \\
\text { polymerase } \\
\text { subunit beta }\end{array}$ & $\begin{array}{l}\text { Possibly polyphyletic NCLDV, with one subset } \\
\text { derived from RNAP1. and another from RNAP2; } \\
\text { likely more recent displacement with RNAP2 in } \\
\text { mimivirus; however, monophyly of NCLDV cannot } \\
\text { be ruled out; loss in most phycodnaviruses. }\end{array}$ \\
\hline
\end{tabular}


Table 1 Evolutionary scenarios for the ancestral NCLDV genes (Continued)

\begin{tabular}{|c|c|c|c|c|c|}
\hline NCVOG0273 & G5.5R & $\begin{array}{l}\text { Transcription and } \\
\text { RNA processing }\end{array}$ & $5 / 15$ & $\begin{array}{l}\text { DNA-directed RNA } \\
\text { polymerase subunit } 5\end{array}$ & $\begin{array}{l}\text { Uncertain, not enough sequence conservation } \\
\text { for reliable phylogenetic analysis }\end{array}$ \\
\hline NCVOG1164 & $\mathrm{A} 1 \mathrm{~L}$ & $\begin{array}{l}\text { Transcription and } \\
\text { RNA processing }\end{array}$ & $6 / 44$ & $\begin{array}{l}\text { A1L transcription } \\
\text { factor/late transcription } \\
\text { factor VLTF-2 }\end{array}$ & $\begin{array}{l}\text { Uncertain, not enough sequence conservation } \\
\text { for reliable phylogenetic analysis }\end{array}$ \\
\hline NCVOG0262 & $\mathrm{A} 2 \mathrm{~L}$ & $\begin{array}{l}\text { Transcription and } \\
\text { RNA processing }\end{array}$ & $6 / 45$ & $\begin{array}{l}\text { Poxvirus Late } \\
\text { Transcription Factor } \\
\text { VLTF3 like }\end{array}$ & $\begin{array}{l}\text { No obvious homologs outside NCLDV } \\
\text { (monophyly of NCLDV by default). }\end{array}$ \\
\hline NCVOG0261 & A7L & $\begin{array}{l}\text { Transcription and } \\
\text { RNA processing }\end{array}$ & $5 / 35$ & $\begin{array}{l}\text { Poxvirus early } \\
\text { transcription factor } \\
\text { (VETF), large subunit } \\
\text { (pfam04441) }\end{array}$ & $\begin{array}{l}\text { No obvious homologs outside NCLDV } \\
\text { (monophyly of NCLDV by default). }\end{array}$ \\
\hline NCVOG0272 & $\mathrm{E} 4 \mathrm{~L}$ & $\begin{array}{l}\text { Transcription and } \\
\text { RNA processing }\end{array}$ & $6 / 39$ & $\begin{array}{l}\text { Transcription factor S-II } \\
\text { (TFIIS)-domain- } \\
\text { containing protein }\end{array}$ & $\begin{array}{l}\text { Uncertain, not enough sequence conservation } \\
\text { for reliable phylogenetic analysis }\end{array}$ \\
\hline NCVOG1127 & One & $\begin{array}{l}\text { Transcription and } \\
\text { RNA processing }\end{array}$ & $4 / 11$ & $\begin{array}{l}\text { transcription initiation } \\
\text { factor IIB }\end{array}$ & Strongly supported monophyly of NCLDV \\
\hline NCVOG0076 & A18R & $\begin{array}{l}\text { Transcription and } \\
\text { RNA processing }\end{array}$ & $6 / 38$ & $\begin{array}{l}\text { DNA or RNA helicases of } \\
\text { superfamily II (COG1061) }\end{array}$ & $\begin{array}{l}\text { Monophyletic NCLDV except for displacement } \\
\text { with a eukaryotic homolog in one phycodnavirus } \\
\text { and acquisition of a distinct eukaryotic paralog } \\
\text { in ASFV }\end{array}$ \\
\hline NCVOG0267 & $18 \mathrm{R}$ & $\begin{array}{l}\text { Transcription and } \\
\text { RNA processing }\end{array}$ & $3 / 23$ & RNA-helicase DExH-NPH-II & $\begin{array}{l}\text { Monophyletic NCLDV; independent losses in } \\
\text { several NCLDV lineages }\end{array}$ \\
\hline NCVOG1117 & D1R & $\begin{array}{l}\text { Transcription and } \\
\text { RNA processing }\end{array}$ & $6 / 33$ & $\begin{array}{l}\text { mRNA capping enzyme } \\
\text { large subunit }\end{array}$ & $\begin{array}{l}\text { Complex, variable domain architecture; apparent } \\
\text { monophyly of NCLDV for the conserved } \\
\text { methyltransferase domain; guanylyltransferases of } \\
\text { apparent distinct eukaryotic origin in a single } \\
\text { iridovirus and a single phycodnavirus }\end{array}$ \\
\hline NCVOG0236 & D9R, D10R & $\begin{array}{l}\text { Transcription and } \\
\text { RNA processing }\end{array}$ & $6 / 29$ & Nudix hydrolase & $\begin{array}{l}\text { Uncertain, not enough sequence conservation for } \\
\text { reliable phylogenetic analysis }\end{array}$ \\
\hline NCVOG1088 & None & $\begin{array}{l}\text { Transcription and } \\
\text { RNA processing }\end{array}$ & $3 / 13$ & RNA ligase & $\begin{array}{l}\text { Monophyletic NCLDV; common origin with } \\
\text { baculovirus and possibly bacteriophage homologs }\end{array}$ \\
\hline- & $J 3 R$ & $\begin{array}{l}\text { Transcription and } \\
\text { RNA processing }\end{array}$ & $2 / 16$ & $\begin{array}{l}\text { PolyA polymerase, } \\
\text { regulatory subunit }\end{array}$ & $\begin{array}{l}\text { Present only in poxviruses and one mimivirus; } \\
\text { however, monophyly strongly supported; possible } \\
\text { ancestral gene }\end{array}$ \\
\hline NCVOG0276 & $\mathrm{F} 4 \mathrm{~L}$ & $\begin{array}{l}\text { Nucleotide } \\
\text { metabolism }\end{array}$ & $6 / 29$ & $\begin{array}{l}\text { Ribonucleotide reductase } \\
\text { small subunit }\end{array}$ & $\begin{array}{l}\text { Polyphyletic NCLDV, complex evolutionary } \\
\text { scenario; ancestral status uncertain; trees similar } \\
\text { for the large and small subunits }\end{array}$ \\
\hline NCVOG1353 & $14 \mathrm{~L}$ & $\begin{array}{l}\text { Nucleotide } \\
\text { metabolism }\end{array}$ & $6 / 24$ & $\begin{array}{l}\text { ribonucleoside diphosphate } \\
\text { reductase, large subunit }\end{array}$ & $\begin{array}{l}\text { Polyphyletic NCLDV, complex evolutionary } \\
\text { scenario; ancestral status uncertain; trees similar } \\
\text { for the large and small subunits }\end{array}$ \\
\hline NCVOG0319 & $J 2 R$ & $\begin{array}{l}\text { Nucleotide } \\
\text { metabolism }\end{array}$ & $5 / 20$ & Thymidine kinase & $\begin{array}{l}\text { Most likely polyphyletic NCLDV although } \\
\text { monophyly could not be statistically rejected }\end{array}$ \\
\hline NCVOG0320 & A48R & $\begin{array}{l}\text { Nucleotide } \\
\text { metabolism }\end{array}$ & $4 / 21$ & Thymidylate kinase & $\begin{array}{l}\text { Most likely polyphyletic NCLDV although } \\
\text { monophyly could not be statistically rejected }\end{array}$ \\
\hline NCVOG1068 & $\mathrm{F} 2 \mathrm{~L}$ & $\begin{array}{l}\text { Nucleotide } \\
\text { metabolism }\end{array}$ & $4 / 30$ & dUTPase (cl00493) & Polyphyletic NCLDV, monophyly rejected \\
\hline NCVOG0022 & D13L & $\begin{array}{l}\text { Virion structure and } \\
\text { morphogenesis }\end{array}$ & $6 / 45$ & $\begin{array}{l}\text { NCLDV major capsid } \\
\text { protein }\end{array}$ & $\begin{array}{l}\text { No homologs outside NCLDV - monophyletic } \\
\text { NCLDV by default }\end{array}$ \\
\hline NCVOG0249 & $\mathrm{A} 32 \mathrm{~L}$ & $\begin{array}{l}\text { Virion structure and } \\
\text { morphogenesis }\end{array}$ & $6 / 45$ & A32-like packaging ATPase & $\begin{array}{l}\text { Only distant homologs outside NCLDV - } \\
\text { monophyletic NCLDV by default }\end{array}$ \\
\hline NCVOG0211 & F9L, L1R & $\begin{array}{l}\text { Virion structure and } \\
\text { morphogenesis }\end{array}$ & $4 / 34$ & $\begin{array}{l}\text { myristylated envelope } \\
\text { protein }\end{array}$ & $\begin{array}{l}\text { No homologs outside NCLDV - monophyletic } \\
\text { NCLDV by default }\end{array}$ \\
\hline NCVOG1122 & $\begin{array}{l}\text { G9R, J5L, } \\
\quad \text { A16L }\end{array}$ & $\begin{array}{l}\text { Virion structure and } \\
\text { morphogenesis }\end{array}$ & $3 / 31$ & $\begin{array}{l}\text { Myristylated protein; } \\
\text { pfam03003, DUF230 }\end{array}$ & $\begin{array}{l}\text { No homologs outside NCLDV - monophyletic } \\
\text { NCLDV by default }\end{array}$ \\
\hline NCVOG0052 & E10R & $\begin{array}{l}\text { Virion structure and } \\
\text { morphogenesis }\end{array}$ & $6 / 44$ & $\begin{array}{l}\text { disulfide (thiol) } \\
\text { oxidoreductase/isomerase; } \\
\text { Erv1 / Alr family (pfam04777) }\end{array}$ & Monophyletic NCLDV \\
\hline
\end{tabular}


Table 1 Evolutionary scenarios for the ancestral NCLDV genes (Continued)

\begin{tabular}{|c|c|c|c|c|c|}
\hline NCVOG0256 & $\mathrm{H} 3 \mathrm{~L}$ & $\begin{array}{l}\text { Virion structure and } \\
\text { morphogenesis }\end{array}$ & $2 / 22$ & $\begin{array}{l}\text { envelope protein, } \\
\text { glycosyltransferase }\end{array}$ & $\begin{array}{l}\text { Apparent monophyletic NCLDV but represented } \\
\text { only in poxviruses and mimiviruses; independent } \\
\text { acquisition cannot be ruled out }\end{array}$ \\
\hline NCVOG0040 & $\mathrm{H} 1 \mathrm{~L}$ & $\begin{array}{l}\text { Signal transduction, } \\
\text { regulation }\end{array}$ & $4 / 30$ & $\begin{array}{l}\text { cd00127, DSPc, Dual } \\
\text { specificity phosphatases } \\
\text { (DSP); Ser/Thr and Tyr } \\
\text { protein phosphatases }\end{array}$ & $\begin{array}{l}\text { Most likely independent acquisitions by } \\
\text { different NCLDV }\end{array}$ \\
\hline NCVOG0330 & $\begin{array}{l}\text { VACWR012, } \\
\text { VACWR207 }\end{array}$ & $\begin{array}{l}\text { Signal transduction, } \\
\text { regulation }\end{array}$ & $5 / 26$ & $\begin{array}{l}\text { RING-finger-containing E3 } \\
\text { ubiquitin ligase } \\
\text { (COG5432: RAD18) }\end{array}$ & $\begin{array}{l}\text { Most likely independent acquisition by different } \\
\text { groups of the NCLDV; probably not an ancestral } \\
\text { gene }\end{array}$ \\
\hline NCVOG0329 & & $\begin{array}{l}\text { Signal transduction, } \\
\text { regulation }\end{array}$ & $2 / 3$ & $\begin{array}{l}\text { UBCc, Ubiquitin-conjugating } \\
\text { enzyme E2 (cd00195) }\end{array}$ & $\begin{array}{l}\text { Present only in mimivirus and ASFV; independent } \\
\text { acquisitions from eukaryotes, NCLDV monophyly } \\
\text { rejected; not an ancestral gene }\end{array}$ \\
\hline NCVOG0246 & & $\begin{array}{l}\text { Signal transduction, } \\
\text { regulation }\end{array}$ & $3 / 4$ & $\begin{array}{l}\text { Ulp1-like protease/ } \\
\text { deubiquitinating enzyme }\end{array}$ & Uncertain, highly diverged NCLDV sequences \\
\hline NCVOG0009 & & $\begin{array}{l}\text { Virus-host } \\
\text { interactions }\end{array}$ & $3 / 4$ & $\begin{array}{l}\text { pfam00653: BIR (Baculovirus } \\
\text { Inhibitor of apoptosis } \\
\text { protein Repeat) domain }\end{array}$ & $\begin{array}{l}\text { Most likely independent acquisition by } \\
\text { different groups of the NCLDV; probably not } \\
\text { an ancestral gene }\end{array}$ \\
\hline NCVOG0012 & $\begin{array}{l}\text { A33R, A44R, } \\
\text { A40R }\end{array}$ & $\begin{array}{l}\text { Virus-host } \\
\text { interactions }\end{array}$ & $3 / 20$ & $\begin{array}{l}\text { C-type lectin: smart00034, } \\
\text { cd03594, cd03593, pfam00059, } \\
\text { cd00037, pfam05966 }\end{array}$ & $\begin{array}{l}\text { Poorly conserved sequence, most likely } \\
\text { independent acquisitions by different groups } \\
\text { of NCLDV; probably not an ancestral gene }\end{array}$ \\
\hline NCVOG1361 & & Uncharacterized & $6 / 11$ & T5orf172 domain (pfam10544) & $\begin{array}{l}\text { Different domain architectures; most likely } \\
\text { independent acquisition by different groups } \\
\text { of the NCLDV; probably not an ancestral gene }\end{array}$ \\
\hline NCVOG1360 & $\begin{array}{l}\text { VACWR011, } \\
\text { VACWR208 }\end{array}$ & Uncharacterized & $3 / 18$ & $\begin{array}{l}\text { KilA domain (pfam04383); } \\
\text { always present at protein } \\
\text { N-termini except for } \\
\text { mimiviruses. In some proteins } \\
\text { fused to the a RING-finger } \\
\text { domain. }\end{array}$ & $\begin{array}{l}\text { Different domain architectures; most likely } \\
\text { independent acquisition by different groups } \\
\text { of the NCLDV; probably not an ancestral gene }\end{array}$ \\
\hline NCVOG1424 & & Uncharacterized & $3 / 6$ & $\begin{array}{l}\text { Uncharacterized domain; } \\
\text { found downstream of KilA, } \\
\text { BRO, and MSV199 domains. } \\
\text { Also found in some } \\
\text { baculoviruses. }\end{array}$ & $\begin{array}{l}\text { Different domain architectures; most likely } \\
\text { independent acquisition by different groups } \\
\text { of the NCLDV; probably not an ancestral gene }\end{array}$ \\
\hline NCVOG0010 & & Uncharacterized & $4 / 11$ & $\begin{array}{l}\text { pfam02498: Bro-N; BRO } \\
\text { family, N-terminal domain: } \\
\text { This family includes the } \\
\text { N-terminus of baculovirus } \\
\text { BRO and ALI motif proteins. }\end{array}$ & $\begin{array}{l}\text { Different domain architectures; most likely } \\
\text { independent acquisition by different groups } \\
\text { of the NCLDV; probably not an ancestral gene }\end{array}$ \\
\hline NCVOG0059 & & Uncharacterized & $2 / 3$ & $\begin{array}{l}\text { FtsJ-like methyltransferase } \\
\text { family proteins (pfam01728) }\end{array}$ & $\begin{array}{l}\text { Present only in mimivirus and ASFV; monophyly } \\
\text { cannot be ruled out }\end{array}$ \\
\hline
\end{tabular}

The systematic gene names are for the Copenhagen strain of Vaccinia virus except for the names starting with VACWR which are from the WR strain because the respective genes are missing/disrupted in the Copenhagen strain.

and used these to search for homologs from cellular organisms and other viruses. The resulting sequence sets were clustered to include all NCLDV proteins along with representatives of as many major lineages of cellular organisms as possible but also to trim the sets down to a size amenable to detailed phylogenetic analysis (see Methods for the details). For the sequence sets thus selected, ML phylogenetic trees were constructed and examined using the constrained tree approach (see Methods). Specifically, for all trees in which the NCLDV did not appear as a single strongly supported clade, the likelihood of the original tree was compared with the likelihood of a tree constrained for monophyly of
NCLDV. When justified, additional constrained trees, with topologies corresponding to plausible evolutionary scenarios, were analyzed for individual genes. Below we present the results of the constrained phylogenetic tree analysis of the inferred ancestral NCLDV genes.

\section{Genes involved in genome replication, recombination and repair}

The DNA replication of the NCLDV is largely independent of the host replication, and accordingly, genes encoding protein components of the complex replication machinery represent a major part of the NCLDV gene core (Table 1). This is the largest group in the ancestral 
NCLDV gene set that includes 13 genes two of which, the DNA polymerase (DNAP) and the primase-helicase, are central and indispensable to replication and are shared by all viruses of this class (it has been claimed that the primase-helicase was missing in some phycodnaviruses [20]; however, in the process of NCVOG construction [5], this gene was identified in all complete NCLDV genomes, the high sequence divergence in some of the viruses notwithstanding). The B family of DNAPs, to which the NCLDV polymerases belong, includes the main replicative polymerases of all archaea and eukaryotes as well as many bacterial, archaeal and eukaryotic viruses. The unconstrained phylogenetic tree for the DNAP failed to recover an NCLDV clade. Instead, the majority of the NCLDV DNAPs along with the DNAPs of herpesviruses formed a clade with eukaryotic DNAP delta and zeta; a sister group to this large branch was a clade that consisted of poxvirus, asfarvirus and baculovirus DNAPs (Figure 1A). However, constrained trees in which monophyly of the NCLDV was enforced could not be rejected by statistical tests (Additional file 2). Moreover, among the tested trees, the tree in which the NCLDV clade also included baculoviruses (as the sister group to asfarviruses) and herpesviruses as the sister group to the composite NCLDV-baculovirus clade, had the highest associated likelihood although none of the analyzed tree topologies could be statistically rejected (Figure 1B and Additional file 2). Thus, the results of the constrained tree analysis are compatible with the monophyly of the DNAPs of all NCLDV and moreover of all large DNA viruses of eukaryotes. This conclusion contrasts the results of several previous phylogenetic analyses that failed to recover an NCLDV clade but did not report attempts to analyze constrained trees [21-23]. It seems likely that the apparent non-monophyly of the NCLDV in previous studies was caused by branch length effects, in particular acceleration of evolution in some of the viruses resulting in long branch attraction [24] (note the branch length, in particular for Poxviridae in Figure $1 \mathrm{~A}, \mathrm{~B})$ and possibly other artifacts of phylogenetic analysis.

Phylogenetic analysis of the second hallmark viral replication gene, the primase-helicase, revealed a strongly supported clade that included 6 of the 7 NCLDV families: phycodnaviruses belonged to a different, also wellsupported branch together with diverse bacteriophage and bacterial (most likely, prophage) homologs (Figure 1C). In this case, the constrained tree topology that included an NCLDV clade was rejected at a statistically significant level (Additional file 2). Thus, the result of the phylogenetic analysis of the NCLDV primasehelicase appears to be best compatible with the presence of this gene in the ancestral NCLDV followed by displacement with a homologous and functionally analogous protein from a bacteriophage in the ancestor of phycodnaviruses. This appears to be a typical case of xenologous gene displacement [25]).

The third gene involved in replication that is present in a large majority of the NCLDV encodes a FLAP nuclease, an enzyme that is also ubiquitous in cellular life forms and removes single-stranded overhangs from replication and recombination intermediates. Nucleases of this family are essential for replication and in particular recombination in poxviruses [26] but can also assume other functions such as mRNA degradation as is the case in herpesviruses [27]. The phylogenetic tree of FLAP nucleases did not include an NCLDV clade. Instead, poxviruses clustered with bacterial homologs, the only representative in phycodnaviruses (Emiliana huxlei virus) placed within the eukaryotic branch, and the rest of the NCLDV formed a clade with the herpesvirus homologs (Figure 1D). However, a constrained tree with an NCLDV clade (excluding the Emiliana huxlei virus) could not be statistically rejected (Additional file 2). The placement of E. huxlei virus within the eukaryotic subtree was supported by high boostrap values, and monophyly of this virus with the rest of the NCLDV was weakly supported (AU value $<0.1$ ) even if not firmly rejected (Additional file 2). At present we cannot confidently conclude whether the poxvirus FLAP nuclease is monophyletic with those of other NCLDV or evolved through displacement of the ancestral form with a phage homolog. However, even the simplest evolutionary scenario for this gene involves loss of the ancestral gene in phycodnaviruses followed by regain of the eukaryotic homolog by the E. huxlei virus.

The remaining genes in this group are less common in NCLDV although the ML reconstruction mapped them to the last common ancestor; the implication of the inferred ancestral status of these genes is that they have been lost on multiple occasions during the evolution of the NCLDV. Topoisomerase IB is represented in poxviruses, one phycodnavirus and mimiviruses. In the phylogenetic tree, poxviruses form a clade with the phycodnavirus but the position of the mimivirus is uncertain (Figure 2A). The monophyly of the NCLDV could not be statistically rejected, so for this gene there is no convincing indication of displacement in any of the NCLDV.

A greater number of NCLDV encode Topoisomerase II that is unrelated to Topoisomerase IB. The phylogenetic tree of Topo II (Figure 2B) did not include an NCLDV clade, and monophyly of the NCLDV could be statistically rejected, with the implication of independent acquisition of the Topo II gene from eukaryotes in mimiviruses and from a prokaryotic source in crocodile poxvirus, with the provenance of this gene in the rest of the NCLDV remaining uncertain (Additional file 2). In 


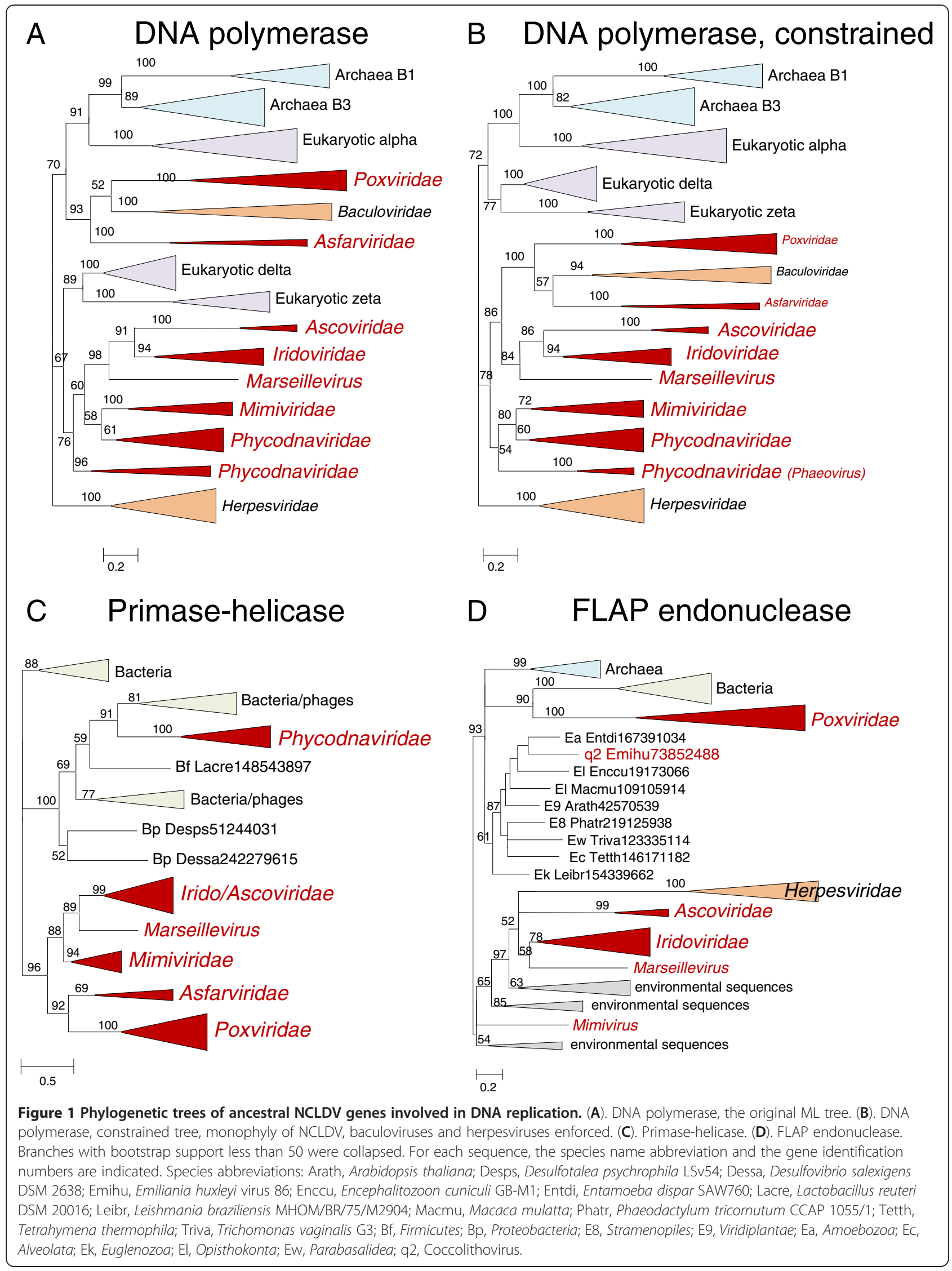




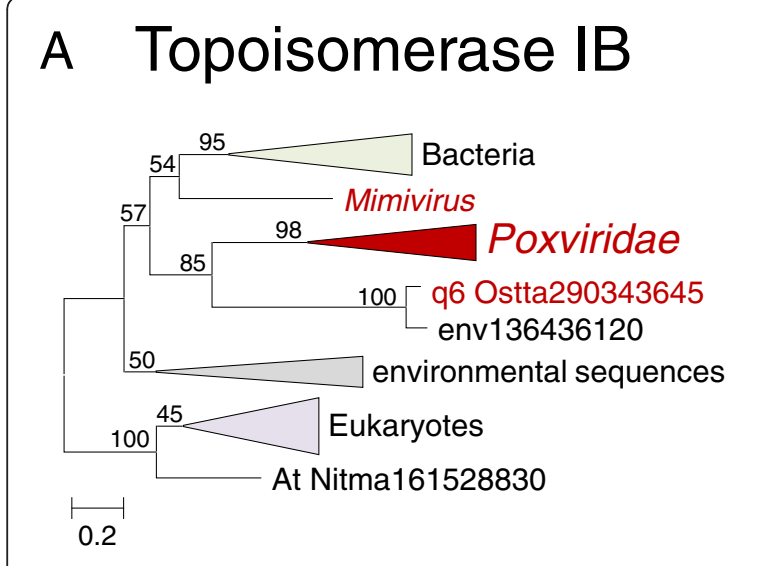

\section{C $\quad$ AP endonuclease 2}

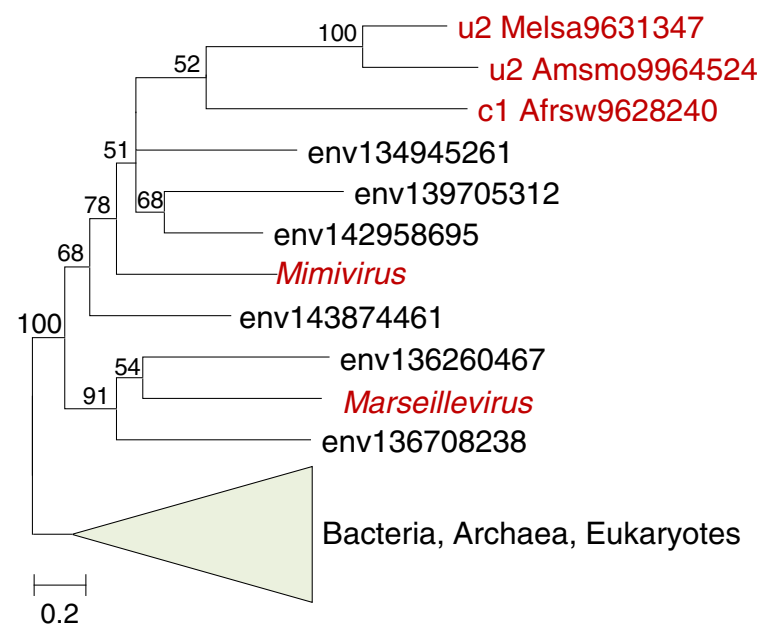

\section{E YqaJ-like recombinase}

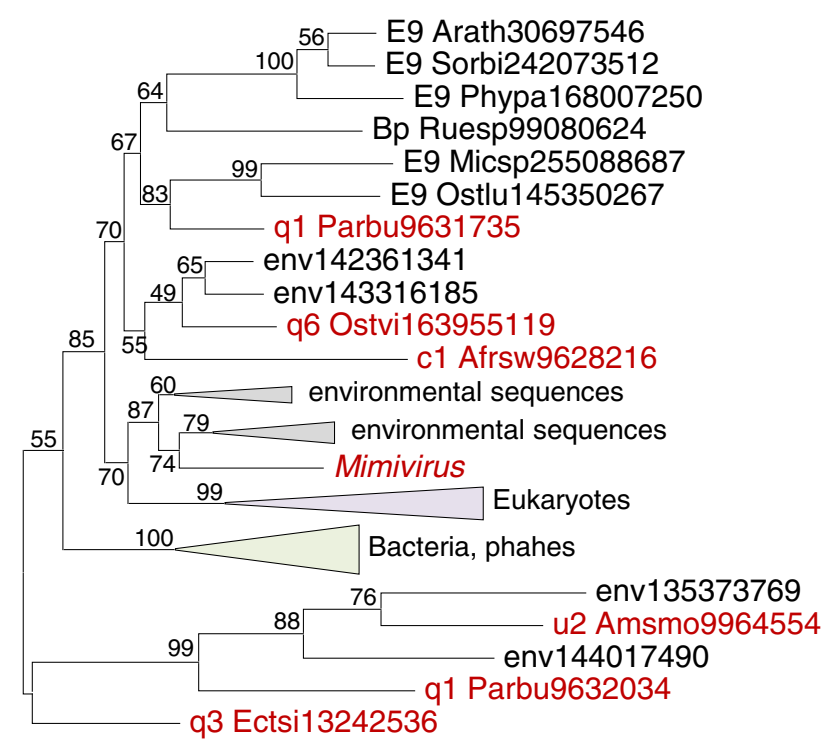

\section{B DNA Topoisomerase II}

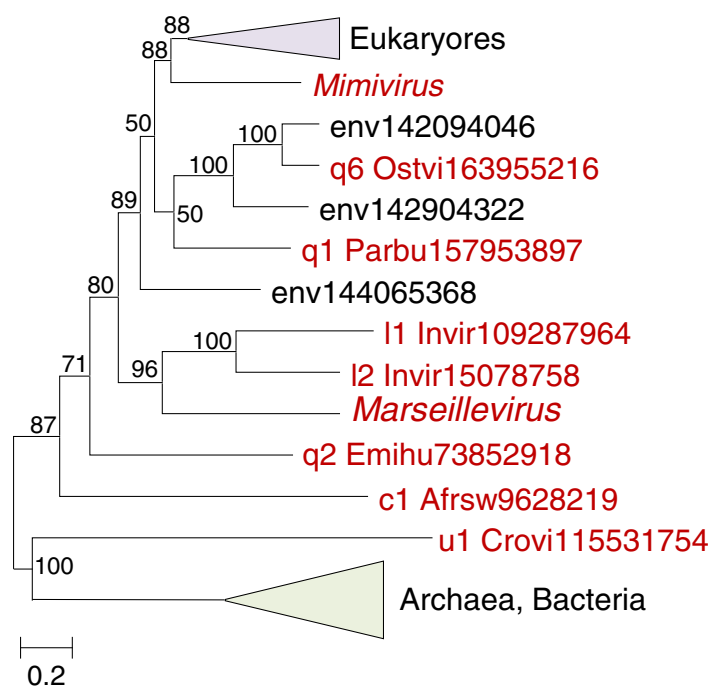

\section{Nucleotidyltransferase}

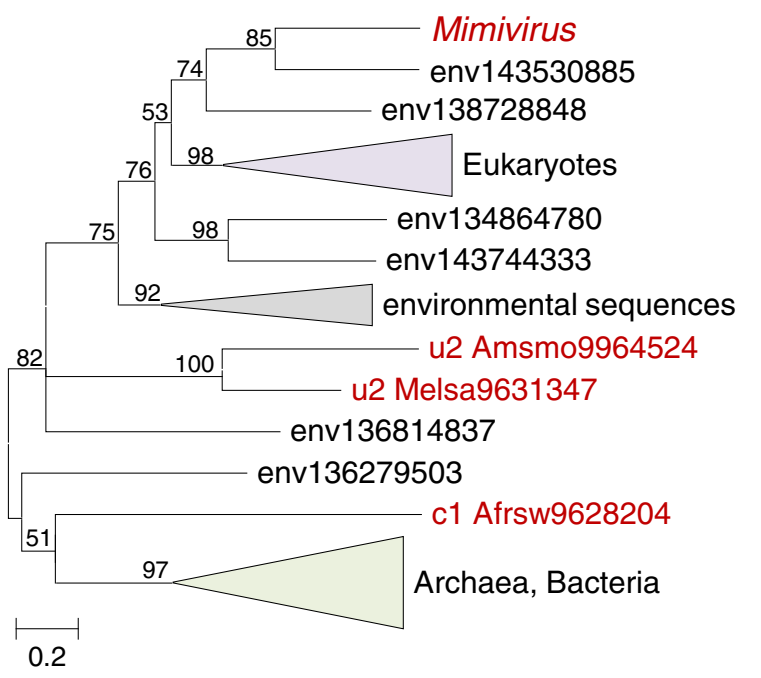

Figure 2 (See legend on next page.) 
(See figure on previous page.)

Figure 2 Phylogenetic trees of ancestral NCLDV genes involved in DNA replication, recombination and repair. (A). Topoisomerase IB. (B). DNA Topoisomerase II. (C). AP endonuclease 2. (D). Nucleotidyltransferase. (E). YqaJ-like recombinase. Branches with bootstrap support less than 50 were collapsed. For each sequence, the species name abbreviation and the gene identification numbers are indicated; env stands for sequences retrieved from env_nr database. Species abbreviations: Invir, Invertebrate iridescent virus; Crovi, Crocodilepox virus; Afrsw, African swine fever virus; Amsmo, Amsacta moorei entomopoxvirus 'L'; Arath, Arabidopsis thaliana; Ectsi, Ectocarpus siliculosus virus 1; Emihu, Emiliania huxleyi virus 86; Ostlu, Ostreococcus lucimarinus CCE9901; Ostta, Ostreococcus tauri virus 1; Ostvi, Ostreococcus virus OsV5; Parbu, Paramecium bursaria Chlorella virus FR483; Phypa, Physcomitrella patens subsp. patens; Melsa, Melanoplus sanguinipes entomopoxvirus; Micsp, Micromonas sp. RCC299; Nitma, Nitrosopumilus maritimus SCM1; Ruesp, Ruegeria sp. TM1040; Sorbi, Sorghum bicolor; At, Thaumarchaeota; Bp, Proteobacteria; E9, Viridiplantae; C1, Asfarviridae; 11, Chloriridovirus; I2, Iridovirus; q1, Chlorovirus; q2, Coccolithovirus; q3, Phaeovirus; q6, unclassified Phycodnaviridae; u1, Chordopoxvirinae; u2, Entomopoxvirinae.

principle, the opposite direction of gene transfer, from specific groups of NCLDV to the respective cellular life forms, cannot be ruled out. However, it appears exceptionally unlikely that, for example, a diverse assortment of bacteria and archaea received the Topo II gene specifically from the crocodile poxvirus lineage.

Phylogenetic analysis of apurinic endonuclease 2 (AP2), a repair enzyme represented in a diverse subset of NCLDV, shows unequivocal support for the monophyly of the NCLDV, assuming that the numerous homologous environmental sequences belong to uncharacterized members of the respective NCLDV groups (Figure 2C). In entomopoxviruses, AP2 is fused with a nucleotidyltransferase (a member of the DNA polymerase beta family) whereas ASFV and mimivirus possess a distinct gene encoding a nucleotidyltransferase. However, the phylogenetic tree of nucleotidyltransferases strongly suggests independent acquisitions of this gene by several NCLDV lineages (Figure 2D).

The phylogenetic tree of the YqaJ family recombinase, an enzyme whose role in NCLDV replication and/or repair remains uncertain, is best compatible with multiple acquisitions from bacteriophages although monophyly of the NCLDV could not be ruled out (Figure 2E and Additional file 2).

The unusual case of two distinct DNA ligases was analyzed in detail previously [18]. Surprisingly, the ATPdependent ligase that is most common among the NCLDV shows clear signs of polyphyletic origin with multiple, independent acquisitions by several virus lineages whereas the less common NAD-dependent ligase appears to be monophyletic, and probably ancestral. A re-analysis performed in the course of this work using an up to date set of sequences provided strong support for this conclusion (Additional file 3).

\section{Genes involved in transcription and mRNA maturation}

All the NCLDV, with the exception of the majority of phycodnaviruses, encode two large subunits of the DNA-dependent RNA polymerase (RNAP) that are also universally conserved in all cellular life forms. It has been reported that in phylogenetic trees the NCLDV RNAP subunits come across as polyphyletic [28,29], and this conclusion is supported by our present analysis (Figure 3A,B). However, for the alpha subunit of the RNAP, the constrained tree in which the NCLDV form a clade, with the exception of the mimivirus and ASFV, actually had the highest likelihood (Figure 3C; Additional file 2). Notably, in this tree the mimivirus gene clustered with the eukaryotic RNAP 2 whereas ASFV clustered with RNAP 1 (Figure 3C), suggestive of two independent displacements of the ancestral NCLDV gene. Similar results were obtained for the RNAP beta subunit: although in this case the original tree with polyphyletic NCLDV had the greatest likelihood, the tree with an NCLDV clade excluding mimivirus and ASFV was nearly as well supported (Additional file 2). As in the case of the alpha subunit, in the RNAP beta subunit tree the mimivirus gene clustered with the eukaryotic RNAP 2 whereas ASFV clustered with RNAP 1 (Figure 3B).

Three additional RNAP subunits/transcription factors were too divergent to reconstruct reliable phylogenetic trees (Table 1). However, for Transcription factor TFIIB, monophyly of the NCLDV was strongly supported (Figure 3D).

Phylogenetic analysis of Superfamily 2 helicases homologous to Vaccinia A18 protein (a helicase involved in late transcription [30]) revealed a strongly supported NCLDV clade, with two NCLDV genes placed in other parts of the tree (Figure 4A). These two anomalies include the E. huxlei phycodnavirus which fell within a bacteriophage cluster and one of the two members of this helicase family encoded by ASFV. Interestingly, this ASFV protein clustered in the tree and shared domain organization with homologs from Kinetoplastida, suggesting the possibility of gene acquisition from unicellular eukaryotes by an ancestral asfarvirus. Monophyly of this Asfarvirus protein with other NCLDV was strongly rejected (Additional file 2). Thus, two Asfarvirus proteins of this family likely have different origins: one is bona fide NCLDV protein whereas another was acquired from a host.

Another family of helicases implicated in transcription includes homologs of Vaccinia D6 and D11 which are 


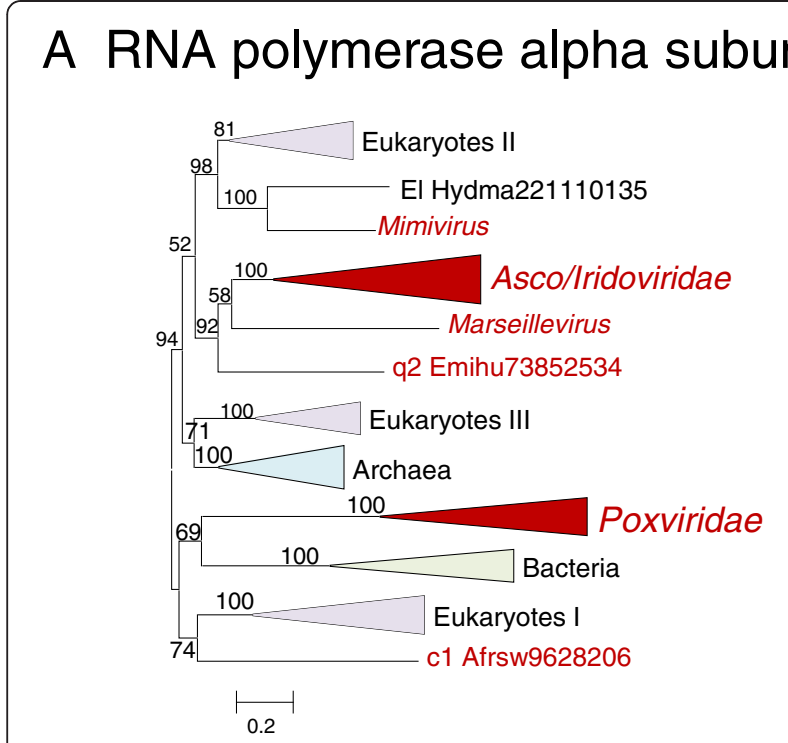

\section{B RNA polymerase beta subunit}

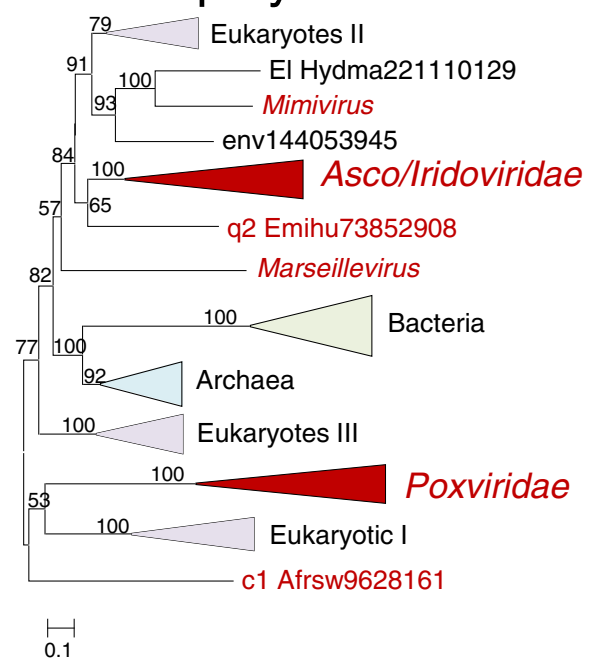

\section{RNA polymerase alpha subunit, constrained}
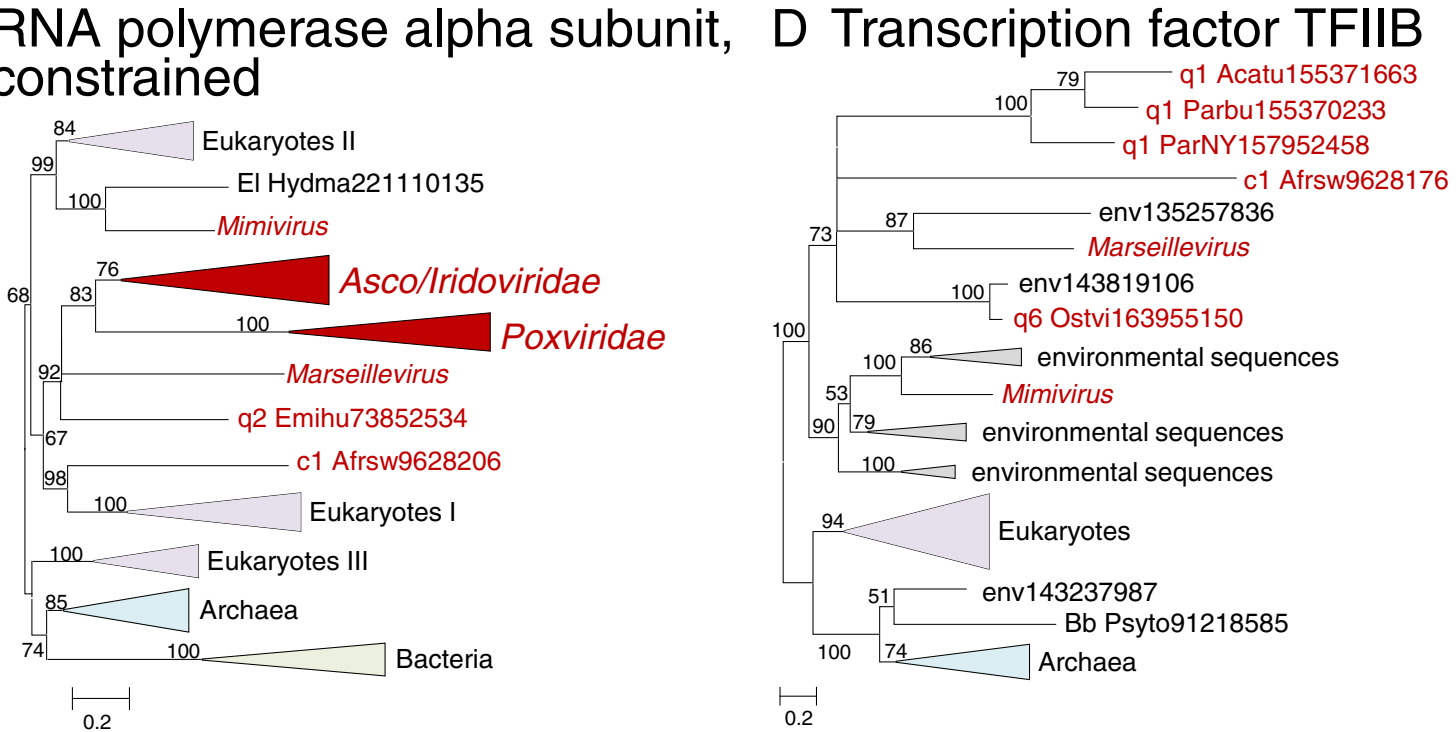

Figure 3 Phylogenetic trees of ancestral NCLDV genes involved in transcription. (A). RNA polymerase alpha subunit. (B). RNA polymerase beta subunit. (C). RNA polymerase alpha subunit, constrained tree with an NCLDV clade excluding mimivirus and ASFV. (D). Transcription factor TFIIB. Branches with bootstrap support less than 50 were collapsed. For each sequence, the species name abbreviation and the gene identification numbers are indicated; env stands for sequences retrieved from env_nr database. Species abbreviations: Acatu, Acanthocystis turfacea Chlorella virus 1; Afrsw, African swine fever virus; Emihu, Emiliania huxleyi virus 86; Hydma, Hydra magnipapillata; Ostvi, Ostreococcus virus OsV5; Parbu, Paramecium bursaria Chlorella virus FR483; ParNY, Paramecium bursaria Chlorella virus NY2A; Psyto, Psychroflexus torquis ATCC 700755; Bb, Bacteroidetes; El, Opisthokonta; c1, Asfarviridae; q1, Chlorovirus; q2, Coccolithovirus; q6, unclassified Phycodnaviridae.

present in ASFV and in mimivirus. Thus, the presence of an ancestral gene of this family in the NCLDV ancestor implies losses in several groups of viruses. Phylogenetic analysis of this gene strongly supports the monophyly of the NCLDV (Figure 4B).

The capping enzyme of the NCLDV is a complex, three-domain protein. The N-terminal phosphatase domain is too divergent for phylogenetic analysis. Phylogenetic analysis of the other two domains, guanylyltransferase and methyltransferase, identifies an NCLDV clade, to the exclusion of the single representative in iridoviruses that appears to be an independent acquisition of a eukaryotic homolog subsequent to the loss of the ancestral NCLDV gene in iridoviruses (Figure 4C,D).

The RNA ligase is an RNA processing enzyme [31] that is represented in by conserved orthologs iridoviruses, ascoviruses, and Marseillevirus and by a more distant homolog in ASFV; the precise role of this enzyme in the NCLDV reproduction remains unclear. In the phylogenetic tree, the NCLDV ligases of the NCLDV 


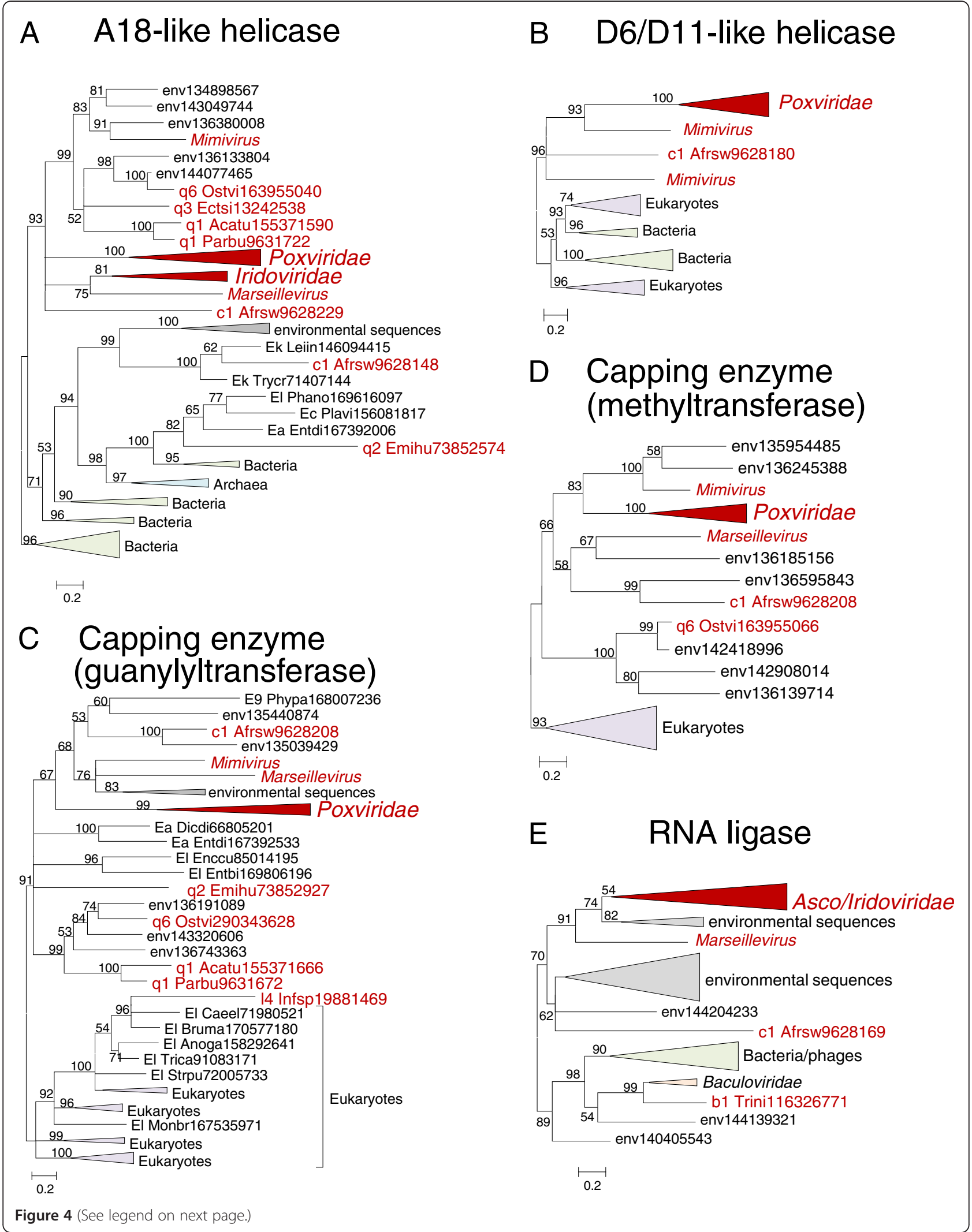




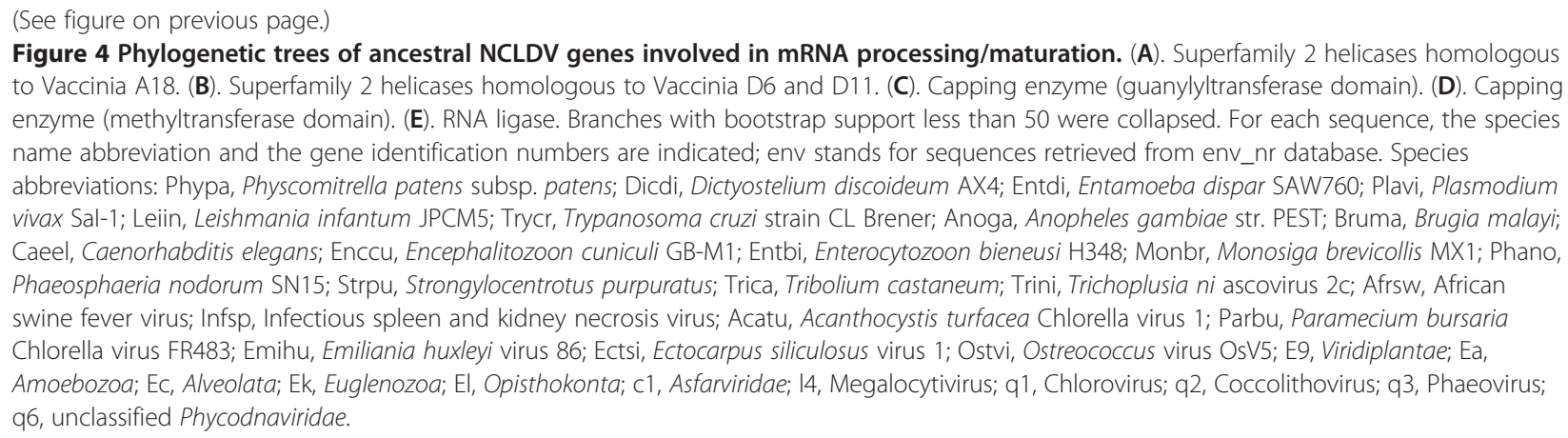

form a well-supported clade (along with many uncharacterized environmental sequences), with the exception of the Trichoplusia $n i$ ascovirus which belonged to a clade with baculovirus and diverse bacteriophages (Figure 4E). The constrained tree with an NCLDV clade was confidently statistically rejected (Additional file 2) indicating that in the Trichoplusia $n i$ ascovirus the RNA ligase genes was displaced by a homolog from a baculovirus.

Finally, the previously investigated case of the small, regulatory subunit of polyA polymerase is unusual in that this gene is present only in poxviruses which also encode the large, catalytic subunit, and in a single mimivirus strain which lacks the catalytic subunit. Despite this sparse representation, the NCLDV small subunits seem to form a strongly supported clade, suggestive of the possibility that this gene was present in the ancestral NCLDV [15].

\section{Genes for enzymes of nucleotide metabolism}

Most of the NCLDV encode varying sets of enzymes involved in metabolism of deoxyribonucleotides. These genes are not strictly essential for virus reproduction, given that knockouts are typically viable in cell cultures, but tend to be important in vivo. The most common enzyme in this group is ribonucleotide reductase (RR) which consists of a large and a small subunits encoded by two distinct genes. The phylogenetic trees of both the large and the small subunits show complex topologies that are incompatible with monophyly of the NCLDV (Figure 5A,B). Moreover, for both subunits, poxviruses and iridoviruses show clear, distinct affinities, with eukaryotic and bacteriophage homologs, respectively. The provenance of the RR in the other NCLDV is less clear. On the whole, it seems to be a safe conclusion that the RR of the NCLDV are not monophyletic but rather have evolved in a complex evolutionary scenario that involved multiple acquisitions, losses and displacement. Therefore, the results of the ML reconstruction notwithstanding, it is difficult to ascertain whether the last common ancestor of the NCLDV encoded RR.
Thymidine kinase (TK) is another major enzyme of dNTP biosynthesis that is present in a large subset of the NCLDV. Phylogenetic analysis reveals three distinct clusters of viral TKs (Figure 6A); a constrained tree containing an NCLDV clade could not be statistically rejected but nevertheless had a lower likelihood than the original tree (Additional file 2). Qualitatively similar results were obtained for Thymidylate kinase (TMPK), the second enzyme of thymidylate biosynthesis (Figure 6B). The dUTPase, an enzyme that functions at the interface of nucleotide metabolism and repair, is present in poxviruses, iridoviruses and many phycodnaviruses, but showed clear signs of polyphyletic origin, including statistically solid rejection of NCLDV monophyly (Figure 6C, Additional file 2). Similar results have been reported from a previous phylogenetic analysis for some of the genes encoding enzymes of nucleotide metabolism [19].

The majority of the sequences of putative ancestral virion proteins and proteins involved in virus morphogenesis and virus-host interactions were too divergent to construct reliable phylogenetic trees. The only exception was the disulfide isomerase enzyme for which monophyly of the NCLDV (including numerous environmental sequences that presumably belong to uncharacterized viruses) could be demonstrated (Figure 7).

\section{Discussion}

Evolutionary reconstruction using patterns of gene presence-absence in viral genomes has led to the conclusion that the NCLDV represent a monophyletic group of viruses that evolved from a common ancestor which was a virus with genomic complexity comparable to that of the extant NCLDV. Approximately 50 genes that are conserved in different subsets of the NCLDV have been assigned to the ancestral virus genome (Table 1), and it appears likely that the ancestral virus additionally encompassed many lineage-specific genes. In this work we went beyond the phyletic patterns by analyzing phylogenies of the inferred ancestral NCLDV genes along with their homologs from cellular organisms. In almost 


\section{A Ribonucleotide reductase, large B Ribonucleotide reductase, small subunit subunit}
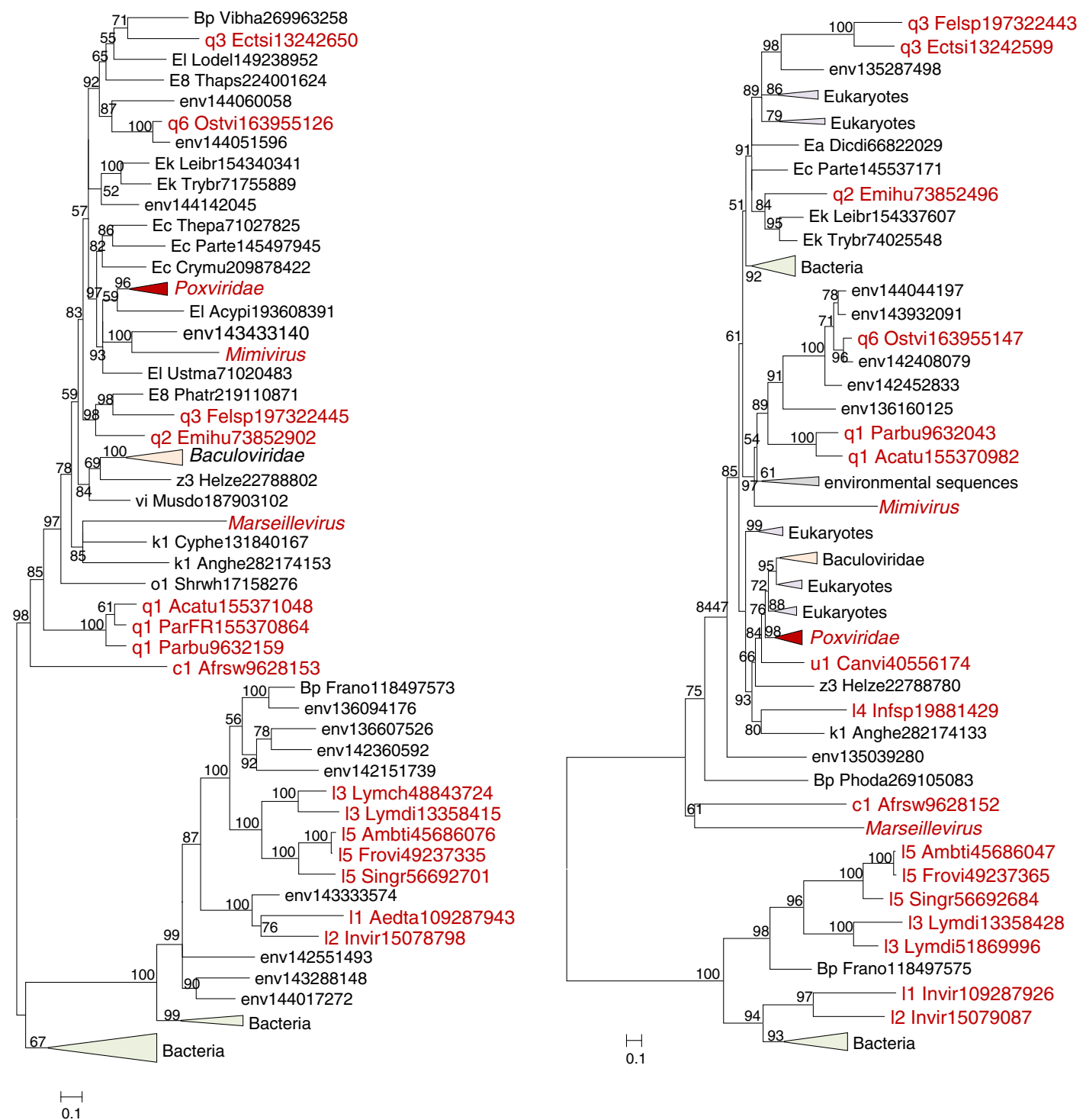

0.1

Figure 5 Phylogenetic trees of the ancestral NCLDV genes for ribonucleotide reductase subunits. (A). Ribonucleotide reductase, large subunit. (B). Ribonucleotide reductase, small subunit. Branches with bootstrap support less than 50 were collapsed. For each sequence, the species name abbreviation and the gene identification numbers are indicated; env stands for sequences retrieved from env_nr database. Species abbreviations: Acatu, Acanthocystis turfacea Chlorella virus 1; Acypi, Acyrthosiphon pisum; Aedta, Invertebrate iridescent virus 3; Afrsw, African swine fever virus; Ambti, Ambystoma tigrinum virus; Anghe, Anguillid herpesvirus 1; Canvi, Canarypox virus; Crymu, Cryptosporidium muris RN66; Cyphe, Cyprinid herpesvirus 3; Dicdi, Dictyostelium discoideum AX4; Ectsi, Ectocarpus siliculosus virus 1; Emihu, Emiliania huxleyi virus 86; Felsp, Feldmannia species virus; Frano, Francisella novicida U112; Frovi, Frog virus 3; Helze, Heliothis zea virus 1; Infsp, Infectious spleen and kidney necrosis virus; 11_Invir, Invertebrate iridescent virus 3; 12_Invir, Invertebrate iridescent virus 6; Leibr, Leishmania braziliensis MHOM/BR/75/M2904; Lodel, Lodderomyces elongisporus NRRL YB-4239; Lymch, Lymphocystis disease virus - isolate China; Lymdi, Lymphocystis disease virus 1; Musdo, Musca domestica salivary gland hypertrophy virus; Ostvi, Ostreococcus virus OsV5; Parbu, Paramecium bursaria Chlorella virus NY2A; ParFR, Paramecium bursaria Chlorella virus FR483; Parte, Paramecium tetraurelia strain d4-2; Phatr, Phaeodactylum tricornutum CCAP 1055/1; Phoda, Photobacterium damselae subsp. damselae CIP 102761; Shrwh, Shrimp white spot syndrome virus; Singr, Singapore grouper iridovirus; Thaps, Thalassiosira pseudonana CCMP1335; Thepa, Theileria parva strain Muguga; Trybr, Trypanosoma brucei; Ustma, Ustilago maydis 521; Vibha, Vibrio harveyi 1DA3; Bp, Proteobacteria; E8, Stramenopiles; Ea, Amoebozoa; Ec, Alveolata; Ek, Euglenozoa; El, Opisthokonta; c1, Asfarviridae; k1, Herpesvirales; 11, Chloriridovirus; 12, Iridovirus; 13, Lymphocystivirus; 14, Megalocytivirus; 15, Ranavirus; 01, Nimaviridae; q1, Chlorovirus; q2, Coccolithovirus; q3, Phaeovirus; q6, unclassified Phycodnaviridae; u1, Chordopoxvirinae; vi, Nudivirus; z3, unclassified dsDNA viruses. 


\section{A Thymidine kinase}

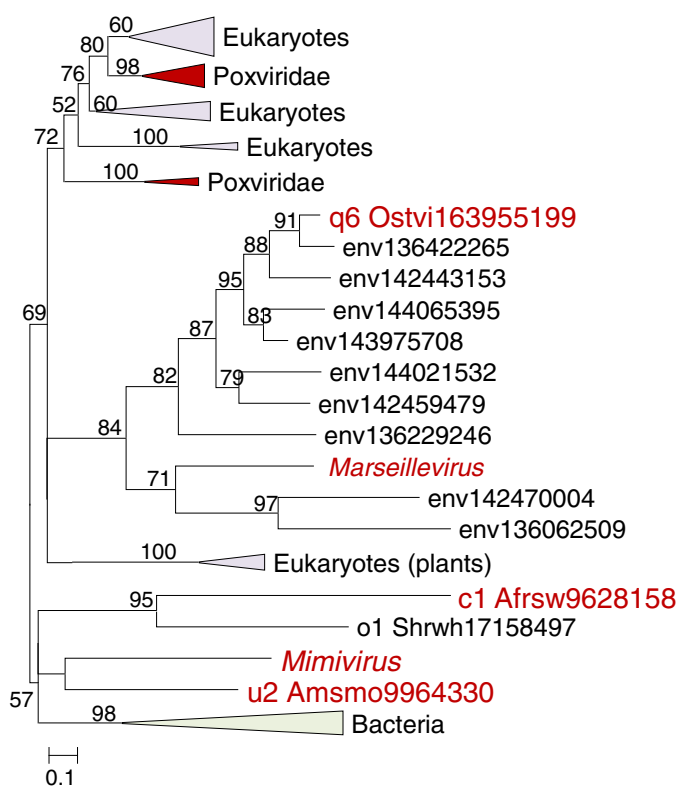

\section{C dUTPase}

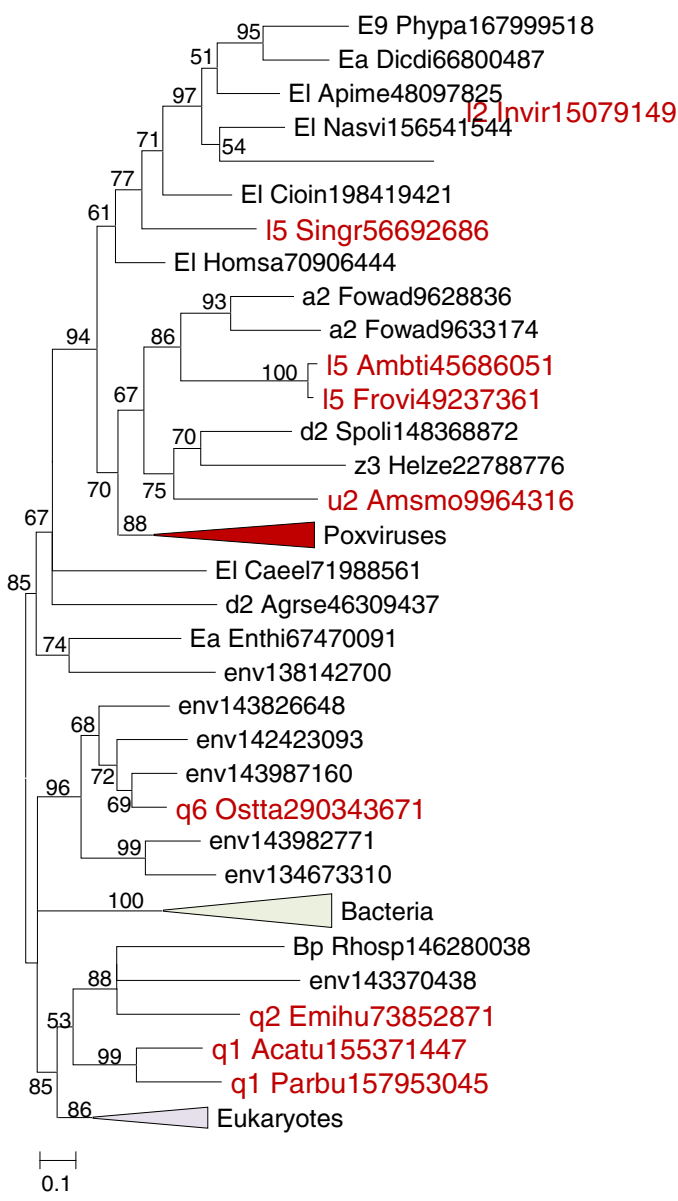

\section{B Thymidylate kinase}

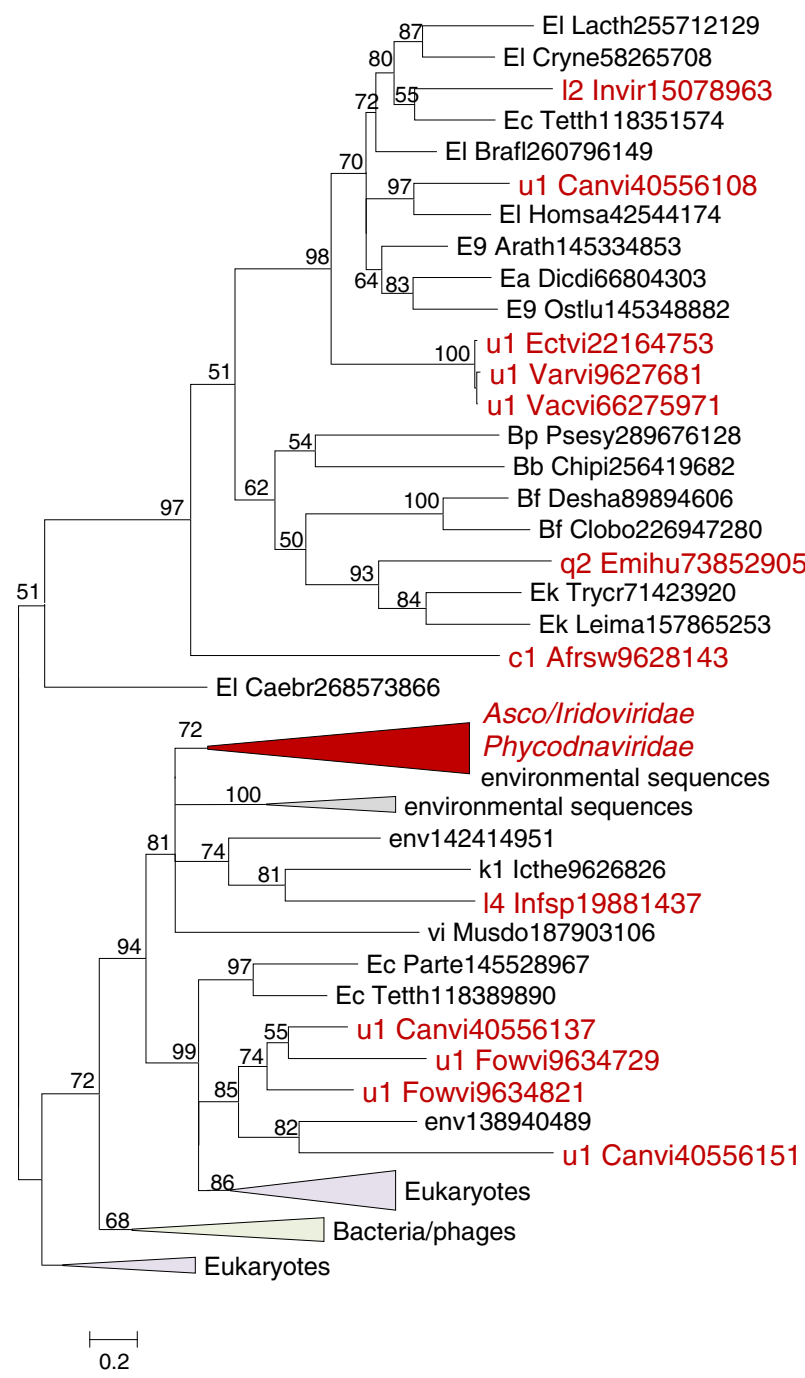

Figure 6 (See legend on next page.) 


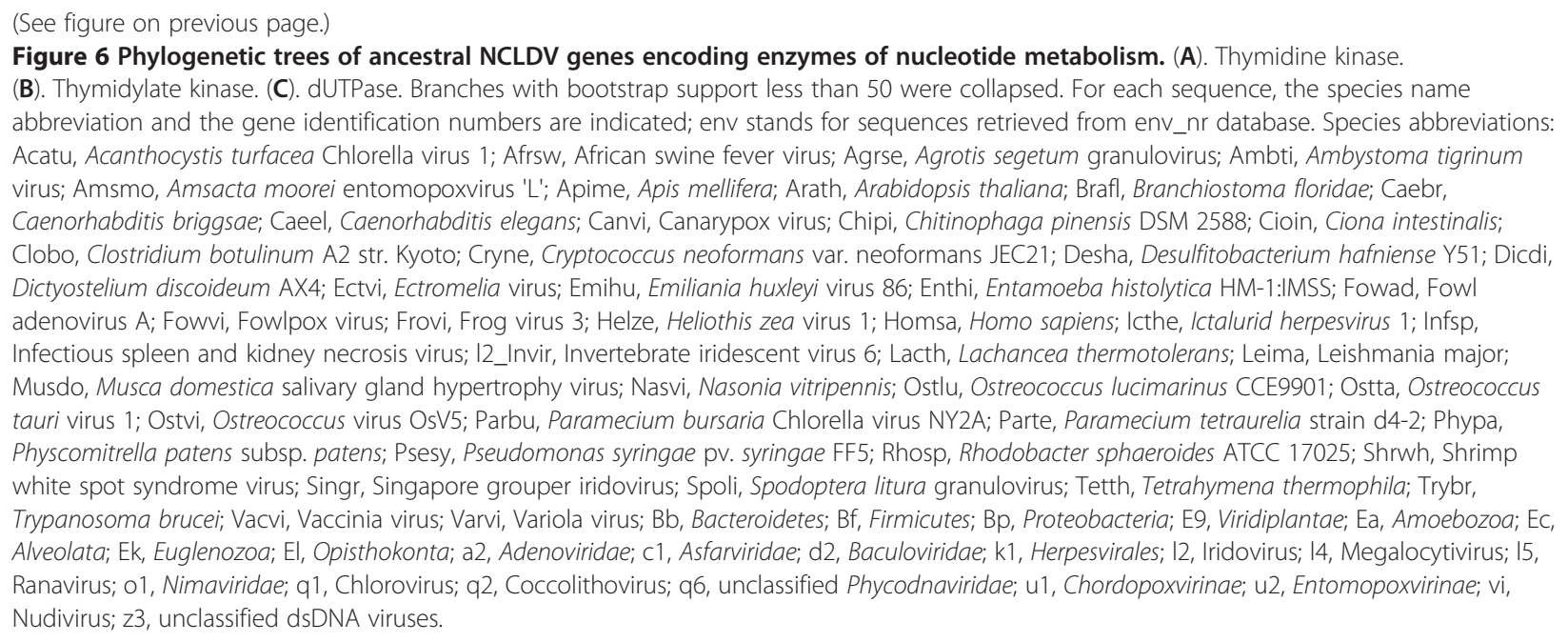

all cases where the information content of the respective multiple sequence alignments was sufficient for phylogenetic analysis, deviations from the simple pattern of vertical evolution were observed (summarized in Table 1). Strikingly, phylogenetic trees for most of the conserved NCLDV genes failed to show an NCLDV clade although it was not always possible to reject the monophyly of the NCLDV at a statistically significant level.

The results of phylogenetic analysis of viral genes have to be interpreted with caution given the generally fast evolution of viral genomes and the ensuing possibility of artifacts such as long branch attraction. Therefore, we considered the monophyly of the NCLDV to be the most appropriate null hypothesis and generally made conclusions on more complex evolutionary scenarios only when this hypothesis could be rejected using conservative statistical tests of tree topology. Nevertheless, even with this conservative approach, phylogenomic analysis suggests that evolution of the core NCLDV genes, with only a few likely exceptions (DNA polymerase, disulfide isomerase and several other genes; see Table 1), included not only multiple gene losses that were apparent already from the examination of the phyletic patterns, but also multiple cases of xenologous gene displacement [25], i.e. displacement of the ancestral gene by a homologous (and functionally analogous) gene from a different source such as bacteriophage or eukaryote. On some occasions, when a gene is missing in a large group of viruses (such as phycodnaviruses) except for a minority of members of that group, in which it is phylogenetically distinct from homologs in other NCLDV, the sequence of events leading to displacement can be inferred as loss followed by regain. In other cases, such as RR and TK, the course of evolution seems to have been too complex to reconstruct the specific scenario.
Thus, the present analysis reveals layers of hidden complexity in the history of the conserved gene core of the NCLDV that are not apparent from the analysis of patterns of gene presence-absence alone [5]. Although deviations from simple vertical evolution probably occurred in the history of almost all core genes, the results do not invalidate the conclusion on the evolution of all known NCLDV from a single ancestral virus. The high prevalence of gene loss and xenologous gene displacement notwithstanding, for most of the core genes, these events affected the evolution of only a few lineages, consistent with the origin of all NCLDV from a common ancestor, followed by isolated events complicating the evolutionary scenarios. However, for several genes that have been included in the core set on the basis of gene presence-absence patterns, such as the enzymes of DNA precursor metabolism, multiple sources are apparent, so that the ancestral status of these genes becomes uncertain.

Phylogenetic analysis of the core NCDLV genes reveals multiple affinities with genes from eukaryotes, bacteria and bacteriophages. The acquisition of genes from eukaryotic hosts (that might not be the same for ancestral and extant viruses) is not surprising. However, gene transfer to NCLDV, in particular those infecting unicellular eukaryotes, from bacteria and bacteriophages is plausible as well given that diverse parasites and symbionts often coexist within the same eukaryotic host. Indeed, in amoebas, with their large cells and phagocytic life style, such coexistence is the norm, making these organisms veritable 'melting pots' of virus evolution $[7,32]$.

The general trend seems to be that bona fide essential genes, are rarely displaced because for these, intermediates lacking the gene are most like non-viable, so if intermediate forms existed, they should have encoded 


\section{Protein disulfide isomerase}

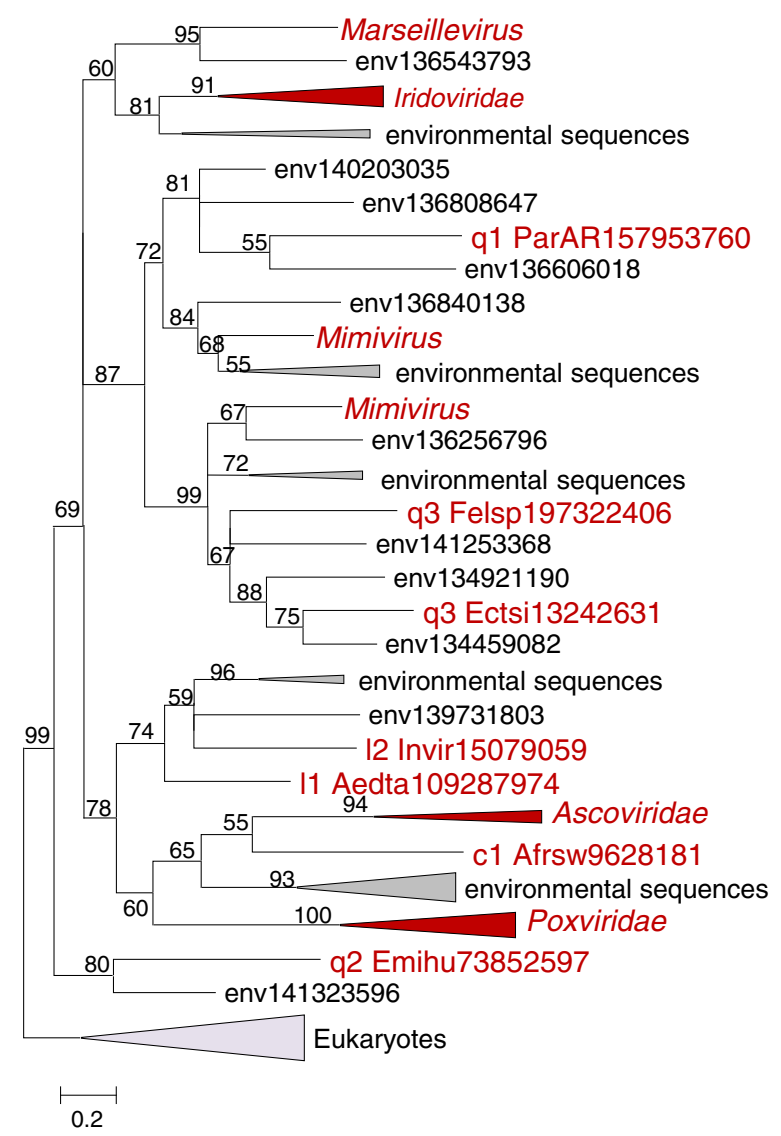

Figure 7 Phylogenetic tree of an ancestral NCLDV gene encoding an enzyme involved in virion morphogenesis: protein disulfide isomerase. Branches with bootstrap support less than 50 were collapsed. For each sequence, the species name abbreviation and the gene identification numbers are indicated; env stands for sequences retrieved from env_nr database. Species abbreviations: Afrsw, African swine fever virus; Aedta, Invertebrate iridescent virus 3; Invir, Invertebrate iridescent virus; ParAR, Paramecium bursaria Chlorella virus AR158; Emihu, Emiliania huxleyi virus 86; Ectsi, Ectocarpus siliculosus virus 1; Felsp, Feldmannia species virus; c1, Asfarviridae; 11, Chloriridovirus; I2, Iridovirus; q1, Chlorovirus; q2, Coccolithovirus; q3, Phaeovirus.

two forms of the respective genes, with the original gene subsequently lost and the xenologous gene retained. This evolutionary scenario might be rare due to the constraints imposed by the requirements for the formation of multisubunit complexes (under the complexity hypothesis of Lake and colleagues [33]), e.g. the replisome. However, the clear-cut xenologous displacement of the primase-helicase gene in phycodnaviruses shows that these obstacles are not insurmountable. In contrast, for genes that are not strictly essential but are beneficial in most virus-host systems, such as the precursor biosynthesis enzymes, parallel loss and regain in multiple lineages seems to be the rule rather than an exception. This pattern can be linked to the viability of evolutionary intermediates lacking the respective genes, at least in the short term.

In addition to cases of xenologous gene displacement, phylogenies of a few core genes point to evolutionary links with other large DNA viruses, such as herpesviruses and baculoviruses, as well as bacteriophages. These observations are compatible with the virus world concept under which viruses are linked through complex networks of evolutionary connections at the level of individual genes and in some cases gene modules, and are also involved in extensive gene exchange with cellular life forms.

\section{Methods}

The NCLDV protein sequences were extracted from the RefSeq database (NCBI, NIH, Bethesda) [34]. The most recently sequenced NCLDV genomes, namely the Cafeteria roenbergensis virus [35], the megavirus [16], both of the Mimiviridae family, and Lausannevirus [8], a close relative of Marseille virus, were not included. For each cluster of orthologous NCLDV genes (NCVOG) that has been mapped to the last common ancestor of the NCLDV [5], the following procedure was applied. A representative NCVOG sequence set was constructed by clustering the complete collection of the respective protein sequences using the Blastclust program (ftp://ftp. ncbi.nih.gov/blast/documents/blastclust.html) and selecting a representative from each cluster of closely related sequences). Two BLASTP runs, one against the Refseq database and the other one against the environmental (env_nr) database at the NCBI, were performed for each representative sequence with the e-value cutoff of 0.1 . This liberal cutoff was used in order to incorporate highly diverged homologs. To eliminate potential false positives, all alignments were examined case by case for the conservation of domain architecture and presence of diagnostic motifs. All the sequences from the given NCVOG, the top 20-30 Refseq hits from each domain of the NCBI Taxonomy (Eukaryota, Bacteria, Archaea, and Viruses), and top 10 environmental hits for each query were combined, and nearly identical sequences were eliminated using Blastclust. The resulting sequences were aligned using MUSCLE [36]; gapped columns (more than $30 \%$ of gaps) and columns with low information content were removed from the alignment [37]. A preliminary tree was constructed using PhyML [38], with the following parameters: WAG substitution matrix; four relative substitution rate categories; the fraction of invariable sites and the alpha parameter of the gamma distribution of site-specific evolution rates) were automatically selected by PhyML. From this preliminary tree, a 
subset of sequences representing each clade were selected and re-aligned. In the next step, 8 PhyML runs were performed for each alignment, with 8 substitution models (Blosum62, Dayhoff, JTT, DCMut, RtREV, CpREV, VT, and WAG). The best topology was chosen by the maximum log likelihood among the 8 trees. Bootstrap branch supports (expressed in Expected-Likelihood Weights, ELW) were calculated using TreeFinder [39] for the best PhyML tree using the best matrix. For detailed phylogenetic analysis, whenever appropriate, alternative (constrained) topology ML trees were constructed using TreeFinder [39], with the substitution model found to be the best for a given alignment in the first-round analysis. Tree topologies were compared with TreeFinder using the approximately unbiased (AU) test $\mathrm{P}$ value [40].

\section{Additional files}

Additional file 1: The phyletic patterns of absence-presence of the NCLDV core genes in the sequenced NCLDV genomes.

Additional file 2: Results of statistical analysis of constrained trees for the core NCLDV genes.

Additional file 3: Phylogenetic trees for the DNA ligases of the NCLDV. A. ATP-dependent ligases. B. NAD-dependent ligases.

\section{Competing interests}

The authors declare that they have no competing interests.

\section{Authors' contributions}

EVK initiated and designed the study; NY collected and analyzed data; EVK wrote the manuscript that was read, edited and approved by both authors.

\section{Acknowledgements}

The authors' research is supported by the DHHS intramural program $(\mathrm{NIH}$, national Library of Medicine).

Received: 10 February 2012 Accepted: 8 August 2012

Published: 14 August 2012

\section{References}

1. Forterre $P$ : The origin of viruses and their possible roles in major evolutionary transitions. Virus Res 2006, 117(1):5-16.

2. Koonin EV, Senkevich TG, Dolja W: The ancient virus world and evolution of cells. Biol Direct 2006, 1(1):29.

3. Iyer LM, Aravind L, Koonin EV: Common origin of four diverse families of large eukaryotic DNA viruses. J Virol 2001, 75(23):11720-11734.

4. Iyer LM, Balaji S, Koonin EV, Aravind L: Evolutionary genomics of nucleo-cytoplasmic large DNA viruses. Virus Res 2006, 117(1):156-184.

5. Yutin N, Wolf Yl, Raoult D, Koonin EV: Eukaryotic large nucleo-cytoplasmic DNA viruses: clusters of orthologous genes and reconstruction of viral genome evolution. Virol J 2009, 6:223.

6. Koonin EV, Yutin N: Origin and evolution of eukaryotic large nucleo-cytoplasmic DNA viruses. Intervirology 2010, 53(5):284-292.

7. Boyer M, Yutin N, Pagnier I, Barrassi L, Fournous G, Espinosa L, Robert C, Azza S, Sun S, Rossmann MG, et al: Giant Marseillevirus highlights the role of amoebae as a melting pot in emergence of chimeric microorganisms. Proc Natl Acad Sci U S A 2009, 106(51):21848-21853.

8. Thomas V, Bertelli C, Collyn F, Casson N, Telenti A, Goesmann A, Croxatto A, Greub G: Lausannevirus, a giant amoebal virus encoding histone doublets. Environ Microbiol 2011, 13(6):1454-1466.
9. Moss B: Poxviridae: the viruses and their replication. In Fields Virology, Volume 2. Edited by Knipe DM, Howley PM. Philadelphia: Lippincott Williams \& Wilkins; 2007:2905-2946.

10. Claverie JM, Abergel C, Ogata H: Mimivirus. Curr Top Microbiol Immunol 2009, 328:89-121.

11. Raoult $D$, Boyer M: Amoebae as genitors and reservoirs of giant viruses. Intervirology 2010, 53(5):321-329.

12. Colson P, Raoult $D$ : Gene repertoire of amoeba-associated giant viruses. Intervirology 2010, 53(5):330-343.

13. Van Etten JL, Lane LC, Dunigan DD: DNA viruses: the really big ones (giruses). Annu Rev Microbiol 2010, 64:83-99.

14. Raoult D, Audic S, Robert C, Abergel C, Renesto P, Ogata H, La Scola B, Suzan M, Claverie JM: The 1.2-megabase genome sequence of Mimivirus. Science 2004, 306(5700):1344-1350.

15. Colson P, Yutin N, Shabalina SA, Robert C, Fournous G, La Scola B, Raoult D, Koonin EV: Viruses with more than 1,000 genes: Mamavirus, a new Acanthamoeba polyphaga mimivirus strain, and reannotation of Mimivirus genes. Genome Biol Evol 2011, 3:737-742.

16. Arslan D, Legendre M, Seltzer V, Abergel C, Claverie JM: Distant Mimivirus relative with a larger genome highlights the fundamental features of Megaviridae. Proc Natl Acad Sci U S A 2011, 108(42):17486-17491.

17. Van Etten JL: Unusual life style of giant chlorella viruses. Annu Rev Genet 2003, 37:153-195.

18. Yutin N, Koonin EV: Evolution of DNA ligases of nucleo-cytoplasmic large DNA viruses of eukaryotes: a case of hidden complexity. Biol Direct 2009, 4:51.

19. Filee J, Pouget N, Chandler M: Phylogenetic evidence for extensive lateral acquisition of cellular genes by Nucleocytoplasmic large DNA viruses. BMC Evol Biol 2008, 8:320.

20. Weynberg KD, Allen MJ, Ashelford K, Scanlan DJ, Wilson WH: From small hosts come big viruses: the complete genome of a second Ostreococcus tauri virus, OtV-1. Environ Microbiol 2009, 11(11):2821-2839.

21. Filee J, Forterre P, Laurent J: The role played by viruses in the evolution of their hosts: a view based on informational protein phylogenies. Res Microbiol 2003, 154(4):237-243.

22. Monier A, Claverie JM, Ogata H: Taxonomic distribution of large DNA viruses in the sea. Genome Biol 2008, 9(7):R106.

23. Ogata H, Toyoda K, Tomaru Y, Nakayama N, Shirai Y, Claverie JM, Nagasaki K: Remarkable sequence similarity between the dinoflagellate-infecting marine girus and the terrestrial pathogen African swine fever virus. Virol J 2009, 6:178.

24. Felsenstein J: Inferring Phylogenies. Sunderland, MA: Sinauer Associates; 2004.

25. Koonin EV, Makarova KS, Aravind L: Horizontal gene transfer in prokaryotes: quantification and classification. Annu Rev Microbiol 2001, 55:709-742.

26. Senkevich TG, Koonin EV, Moss B: Predicted poxvirus FEN1-like nuclease required for homologous recombination, double-strand break repair and full-size genome formation. Proc Natl Acad Sci U S A 2009, 106(42):17921-17926.

27. Everly DN Jr, Feng P, Mian IS, Read GS: mRNA degradation by the virion host shutoff (Vhs) protein of herpes simplex virus: genetic and biochemical evidence that Vhs is a nuclease. J Virol 2002, 76(17):8560-8571.

28. Sonntag KC, Darai G: Evolution of viral DNA-dependent RNA polymerases. Virus Genes 1995, 11(2-3):271-284.

29. Lane WJ, Darst SA: Molecular evolution of multisubunit RNA polymerases: sequence analysis. J Mol Biol 2010, 395(4):671-685.

30. Lackner CA, Condit RC: Vaccinia virus gene A18R DNA helicase is a transcript release factor. J Biol Chem 2000, 275(2):1485-1494.

31. Pascal JM: DNA and RNA ligases: structural variations and shared mechanisms. Curr Opin Struct Biol 2008, 18(1):96-105.

32. Moliner C, Fournier PE, Raoult D: Genome analysis of microorganisms living in amoebae reveals a melting pot of evolution. FEMS Microbiol Rev 2010, 34:281-294.

33. Jain R, Rivera MC, Lake JA: Horizontal gene transfer among genomes: the complexity hypothesis. Proc Natl Acad Sci U S A 1999, 96(7):3801-3806.

34. Sayers EW, Barrett T, Benson DA, Bolton E, Bryant SH, Canese K, Chetvernin V, Church DM, Dicuccio M, Federhen S, et al: Database resources of the National Center for Biotechnology Information. Nucleic Acids Res 2012, 40(Database issue):D13-D25.

35. Fischer MG, Allen MJ, Wilson WH, Suttle CA: Giant virus with a remarkable complement of genes infects marine zooplankton. Proc Natl Acad Sci U S A 2010, 107(45):19508-19513. 
36. Edgar RC: MUSCLE: multiple sequence alignment with high accuracy and high throughput. Nucleic Acids Res 2004, 32(5):1792-1797.

37. Yutin N, Makarova KS, Mekhedov SL, Wolf YI, Koonin EV: The deep archaeal roots of eukaryotes. Mol Biol Evol 2008, 25(8):1619-1630.

38. Guindon S, Gascuel O: A simple, fast, and accurate algorithm to estimate large phylogenies by maximum likelihood. Syst Biol 2003, 52(5):696-704.

39. Jobb G, von Haeseler A, Strimmer K: TREEFINDER: a powerful graphical analysis environment for molecular phylogenetics. BMC Evol Biol 2004, 4:18.

40. Shimodaira $\mathrm{H}$ : An approximately unbiased test of phylogenetic tree selection. Syst Biol 2002, 51(3):492-508.

doi:10.1186/1743-422X-9-161

Cite this article as: Yutin and Koonin: Hidden evolutionary complexity of Nucleo-Cytoplasmic Large DNA viruses of eukaryotes. Virology Journal 2012 9:161.

\section{Submit your next manuscript to BioMed Central and take full advantage of:}

- Convenient online submission

- Thorough peer review

- No space constraints or color figure charges

- Immediate publication on acceptance

- Inclusion in PubMed, CAS, Scopus and Google Scholar

- Research which is freely available for redistribution 